\title{
An international SUrvey on non-iNvaSive tecHniques to assess the mlcrocirculation in patients with RayNaud's phEnomenon (SUNSHINE survey)
}

DOI:

10.1007/s00296-017-3808-0

\section{Document Version}

Accepted author manuscript

Link to publication record in Manchester Research Explorer

Citation for published version (APA):

Ingegnoli, F., Ughi, N., Dinsdale, G., Orenti, A., Boracchi, P., Allanore, Y., Foeldvari, I., Sulli, A., Cutolo, M., Smith, V., Herrick, A. L., Hij, A., Sulli, A., Nitsche, A., Vacca, A., Balbir-Gurman, A., Abdessemed, A., Vargas, A., Valenzuela, A., ... The Eular Study Group On Microcirculation In Rheumaticdiseases (2017). An international SUrvey on non-iNvaSive tecHniques to assess the mlcrocirculation in patients with RayNaud's phEnomenon (SUNSHINE survey). Rheumatology International, 37(11), 1879-1890. https://doi.org/10.1007/s00296-017-3808-0

Published in:

Rheumatology International

\section{Citing this paper}

Please note that where the full-text provided on Manchester Research Explorer is the Author Accepted Manuscript or Proof version this may differ from the final Published version. If citing, it is advised that you check and use the publisher's definitive version.

\section{General rights}

Copyright and moral rights for the publications made accessible in the Research Explorer are retained by the authors and/or other copyright owners and it is a condition of accessing publications that users recognise and abide by the legal requirements associated with these rights.

\section{Takedown policy}

If you believe that this document breaches copyright please refer to the University of Manchester's Takedown Procedures [http://man.ac.uk/04Y6Bo] or contact uml.scholarlycommunications@manchester.ac.uk providing relevant details, so we can investigate your claim.

\section{OPEN ACCESS}


Running header: survey on techniques to assess Raynaud's phenomenon

\title{
An international SUrvey on non-iNvaSive tecHniques to assess the mlcrocirculation in patients with RayNaud's phEnomenon (SUNSHINE survey)
}

\author{
Francesca Ingegnoli ${ }^{1}$, Nicola Ughi ${ }^{1}$, Graham Dinsdale $^{2}$, Annalisa Orenti ${ }^{3}$, Patrizia \\ Boracchi $^{3}$, Yannick Allanore ${ }^{4}$, Ivan Foeldvari ${ }^{5}$, Alberto Sulli ${ }^{6}$, Maurizio Cutolo ${ }^{6}$, Vanessa \\ Smith ${ }^{7}$, Ariane L Herrick ${ }^{2,8}$, on behalf of the EULAR Study Group on Microcirculation in \\ Rheumatic Diseases
}

Study group list of co-authors is reported below.

${ }^{1}$ Division of Rheumatology, ASST Gaetano Pini, Dept. of Clinical Sciences and Community Health, Università degli Studi di Milano, Milano, Italy

${ }^{2}$ Centre for Musculoskeletal Research, The University of Manchester, Salford Royal NHS Foundation Trust, Manchester Academic Health Science Centre, Manchester, UK

${ }^{3}$ Laboratory of Medical Statistics, Epidemiology and Biometry G.A. Maccacaro, Dept. of Clinical Sciences and Community Health, Università degli Studi di Milano, Milano, Italy

${ }^{4}$ Paris Descartes University and Cochin Hospital, AP-HP, Paris, France

${ }^{5}$ Hamburger Zentrum für Kinder- und Jugend Rheumatologie, Klinikum Eilbek, Hamburg, Germany

${ }^{6}$ Research Laboratory and Academic Division of Clinical Rheumatology, Department of Internal Medicine, University of Genova, Genova, Italy

${ }^{7}$ Department of Rheumatology, Ghent University Hospital, Ghent, Ghent University, Belgium 
${ }^{8} \mathrm{NIHR}$ Manchester Musculoskeletal Biomedical Research Unit, Central Manchester NHS

Foundation Trust, Manchester Academic Health Science Centre, UK.

SUrvey on non-iNvaSive tecHniques to assess the mlcrocirculation in patients with RayNaud's phEnomenon (SUNSHINE) study group: list of co-authors (in alphabetical order):

Abud Mendoza Carlos, Departamento de Reumatología y Patología, Hospital Central Dr. Ignacio Morones Prieto, Universidad Autónoma de San Luis Potosí, San Luis, Mexico; Alvarez Hernández Everardo, Servicio de Reumatología, Hospital General de México, Mexico D.F., Mexico; Abdessemed Amina, Rheumatology Department, EPH Benaknoun, Algiers, Algeria; Akikusa Jonathan, Murdoch Childrens Research Institute and Royal Children's Hospital, Parkville, Victoria, Australia; Aktay Ayaz Nuray, Istanbul Kanuni Sultan Süleyman Education and Research Hospital, Istanbul, Turkey; Ananyeva Lidia, Rheumatology Department, Institute of Rheumatology, Russian Academy of Medical Science, Moscow, Russia; Ancuta Codrina, Gr. T. Popa University of Medicine and Pharmacy, Rehabilitation Hospital, Iasi, Romania; Audisio Marcelo J, Hospital Nacional de Clínicas, Córdoba, Argentina; Balbir-Gurman, Alexandra, The B. Shine Rheumatology Unit, Rambam Health Care Campus, Rappaport Faculty of Medicine, Haifa, Israel; Baranauskaite Asta, Lithuanian University of Health Sciences, Kaunas, Lithuania; Barešić Marko, Division of Clinical Immunology and Rheumatology, Internal Medicine Department, University Hospital Center Zagreb, Zagreb, Croatia; Bečvář Radim, Institute of Rheumatology and Department of Rheumatology of the First Faculty of Medicine, Charles University in Prague, Prague, Czech Republic; Becker Mike, Rheumatology and Clinical Immunology, Charité University Hospital, Berlin, Germany; Belloli Laura, S.C. Reumatologica, A.O. Ospedale Niguarda Ca' Granda, Milan, Italy; Benseler Susa, Department of Pediatrics, Alberta Children's Hospital Research Institute Faculty of Medicine, University of Calgary, Calgary, Canada; Beretta Lorenzo, Referral Center for Systemic Autoimmune Diseases, Fondazione IRCCS Ca' Granda Ospedale Maggiore Policlinico di Milano, Milan, Italy; Bertolazzi Chiara, Rheumatology department, Instituto Nacional de Rehabilitación, Luis Guillermo Ibarra Ibarra, Mexico City, Mexico; Bica Blanca E, Rheumatology Unit, Universidade Federal do Rio de Janeiro, Rio de Janeiro, Brazil; Boin Francesco, Department of Medicine, Division of Rheumatology, University of California, San Francisco, USA; Braun-Moscovici Yolanda, The B. Shine Rheumatology Unit, Rambam Health Care Campus, Rappaport Faculty of Medicine, Haifa, Israel; Caramaschi Paola, Rheumatology Unit, Policlinico G.B. Rossi, University of Verona, Verona, Italy; Chizzolini Carlo, Immunollogy \& Allergy, University Hospital and School of Medicine, Geneva, Switzerland; Cimaz Rolando, Department of Pediatrics, Rheumatology Unit, Anna Meyer Children's Hospital and University of Florence, Italy; Cracowski JeanLuc, Université Grenoble-Alpes, HP2, Grenoble, France; Curran Megan, Department of Pediatrics, Northwestern University Feinberg School of Medicine, Chicago, USA; Daikeler 
Thomas, Rheumatology, University Hospital, Basel, Switzerland; De Angelis Rossella, Rheumatology Department, Polytechnic University of the Marche, Jesi, Italy; De Araujo Daniel B, Rheumatology Department, Hospital do Servidor Público Estadual de São Paulo, São Paulo, Brazil; De la Puente Carlos, Servicio de Reumatología, Hospital Ramon Y Cajal, Madrid, Spain; Derfalvi Beata, Dalhousie University, IWK Health Centre, Halifax, Canada; Distler Oliver, Division of Rheumatology, University Hospital Zurich, Zurich, Switzerland; Dobrev Hristo, Department of Dermatology and Venereology, Medical University, Plovdiv, Bulgaria; Dobrota Rucsandra, Division of Rheumatology, University Hospital Zurich, Zurich, Switzerland; De Langhe Ellen, Department of Rheumatology, University Hospital Leuven, Leuven, Belgium; Hachulla Eric, Service de Médecine Interne, Centre National de Référence des Maladies Autoimmunes, Hôpital Claude Huriez CHRU, Lille, France; Fathi Nihal, Department of Rheumatology and Rehabilitation, Sohag University, Sohag, Egypt; Fragoso Loyo Hilda, Department of Immunology and Rheumatology, Instituto Nacional de Ciencias Médicas y Nutrición Salvador Zubirán, México City, México; Frech Tracy, Division of Rheumatology, Department of Internal Medicine, University of Utah, Salt Lake City, USA; García de la Peña Lefebvre Paloma, Servicio de Reumatología, Hospitales Universitarios Grupo Madrid, Madrid, Spain; Guiducci Serena, Department of Experimental and Clinical Medicine, Division of Rheumatology, University of Florence, Florence, Italy; Gutierrez Marwin, Division of Musculoskeletal Diseases, Instituto Nacional de Rehabilitación, Luis Guillermo Ibarra Ibarra, Mexico City, Mexico; Hasler Paul, Department of Rheumatology, Cantonal Hospital Aarau, Aarau, Switzerland; Hermann Walter, Internal Medicine \& Rheumatology Department, Justus-Liebig-University Giessen, Kerckhoff-Klinik, Bad Nauheim, Germany; Hernandez Molina Gabriela, Immunology and Rheumatology Department, Instituto Nacional de Ciencias Médicas y Nutrición Salvador Zubirán, Mexico City, Mexico; Hesselstrand Roger, Rheumatology Department, Lund University, Lund, Sweden; Hij Adrian, Département de Médecine Interne et Pathologie Vasculaire, Hôpital Saint Louis, Université Paris 7, APHP, Paris, France.; Hufnagel Markus, Division of Pediatric Infectious Diseases and Rheumatology, University Medical Center Freiburg, Freiburg, Germany; Hughes Michael, Centre for Musculoskeletal Research, The University of Manchester, Salford Royal NHS Foundation Trust, Manchester Academic Health Science Centre, Manchester, UK; Ickinger Claudia, Division of Rheumatology, Faculty of Health Sciences, Chris Hani Baragwanath Academic Hospital, University of the Witwatersrand, Johannesburg, South Africa; Inanç Murat, Internal Medicine Department, Division of Rheumatology, Istanbul University, Istanbul, Turkey; Irace Rosaria, Rheumatology Unit, Department of Internal and Experimental Medicine, Second University of Naples, Naples, Italy; Janta lustina, Rheumatology Department, Hospital General Universitario Gregorio Marañón, Madrid, Spain; Kayser Cristiane, Rheumatology Division, Universidade Federal de São Paulo, São Paulo, Brazil; Khan Ajaz Kariem, Khyber Medical Institute Srinagar, India; Khanna Dinesh, Division of Rheumatology, Internal Medicine Department, University of Michigan, Ann Arbor, USA; Krasowska Dorota, Department of Dermatology, Venereology and Paediatric Dermatology, Medical University of Lublin, Poland; Kubo Satoshi, The First Department of Internal Medicine, University of Occupational and Environmental Health, Fukuoka, Japan; Lewandowski Laura, National Institute of Arthritis and Musculoskeletal and Skin Diseases, National Institutes of Health, Bethesda, Maryland, 
USA. Longo Francisco J, Servicio de Reumatología, Hospital General Universitario Gregorio Marañón, Madrid, Spain. Lambova Sevdalina, Department of Propedeutics in Internal Medicine, Medical University, Plovdiv, Bulgaria; Launay David, Département de Médecine Interne et Immunologie Clinique, Lille University, Lille, France; Lima Rodrigo, Serviço de Reumatologia, Hospital de Base do Distrito Federal, Brasília, Brasil; Loyo Esthela, Servicio de Reumatología e Inmunología Clinica HRUJMCB, Jefe de Servicio, Santiago, Rep. Dominicana; Müller Ladner Ulf, Department of Rheumatology and Clinical Immunology, Kerckhoff-Klinik, Justus-Liebig University Giessen, Bad Nauheim, Germany; Makol Ashima, Department of Medicine, Division of Rheumatology, Mayo Clinic College of Medicine, Rochester, USA; Mamani Marta N, Servicio de Reumatología, Hospital Bernardino Rivadavia, Buenos Aires, Argentina; Kaliterna Dušanka $M$, Division of Rheumatology and Clinical Immunology, University Hospital Center of Split, Split, Croatia; Michalska Jakubus Małgorzata, Department of Dermatology, Venereology and Pediatric Dermatology, Medical University of Lublin, Lublin, Poland; Mihai Carina, Carol Davila University of Medicine and Pharmacy, Bucharest, Romania; Milchert Marcin, Department of Rheumatology and Internal Medicine of Pomeranian Medical University, Szczec, Poland; Minier Tünde, Department of Rheumatology and Immunology, University of Pécs, Pécs, Hungary; Molina Maria J, Rheumatology Department, Hospital Central de San Isidro, Buenos Aires, Argentina; Moraes Fontes Maria F, Unidade de Doenças Autoimunes, Hospital Curry Cabral, Centro Hospitalar de Lisboa Central, Lisbon, Portugal; Moroncini Gianluca, Dipartimento di Scienze Cliniche e Molecolari, Università Politecnica delle Marche \& Clinica Medica, Ospedali Riuniti Ancona, Ancona, Italy; Naredo Esperanza, Department of Rheumatology, Hospital General Universitario Gregorio Marañón, Madrid, Spain; Nieto-Gonzàlez, Juan Carlos Department of Rheumatology, Hospital General Universitario Gregorio Marañón, Madrid, Spain; Nitsche Alejandro, Servicio de Reumatología, Hospital Alemán, Buenos Aires, Argentina; Ostojic Predrag, Institute of Rheumatology, University of Belgrade, Belgrade, Serbia; Pain Clare, Department of Paediatric Rheumatology, Alder Hey Children's NHS Foundation Trust, Liverpool, UK; Pamuk Ömer N, Division of Rheumatology, Trakya University Medical Faculty, Edirne, Turkey; Pauling John, Royal National Hospital for Rheumatic Diseases, Bath, UK; Payne-Poff Sarah, Greenville Health Systems Pediatric Rheumatology, Greenville, USA; Petraitis Mykolas, Hospital of Lithuanian, University of Health Sciences Kaunas Clinics, Kaunas, Lithuania; Petty Ross, British Columbia Children's Hospital, University of British Columbia, Vancouver, Canada; Popa Serghei,Department of Rheumatology, Republican Clinical Hospital, Chisinau, Republic of Moldova; Puszczewicz Mariusz, Department of Rheumatology and Internal Disease, University of medical Sciences ,Poznan University of Medical Science, Poznan, Poland; Riccieri Valeria, Department of Internal Medicine and Medical Specialities, University of Rome La Sapienza, Rome, Italy; Riemekasten Gabriela, Clinic for Rheumatology, University of Lübeck, Lübeck, Germany; Rednic Simona, Department of Rheumatology, Clinical County Emergency Hospital, Cluj-Napoca, Romania; Rodríguez Reyna Tatiana S, Department of Immunology and Rheumatology, Instituto Nacional de Ciencias Médicas y Nutrición Salvador Zubirán, Mexico City, Mexico; Romanowska Próchnicka Katarzyna, Department of General and Experimental Pathology, Warsaw Medical University, Warsaw, Poland; Rosato Edoardo, Department of Clinical Medicine, Clinical Immunology Unit, Sapienza 
University of Rome, Italy; Rouster Stevens Kelly, Children's Healthcare of Atlanta, Emory University School of Medicine, Atlanta, USA; Saketkoo Lesley A, New Orleans Scleroderma and Sarcoidosis Patient Care and Research Center, Tulane University Lung Center, New Orleans, USA; Sander Oliver, Poliklinik und Funktionsbereich für Rheumatologie \& Hiller Forschungszentrum Rheumatologie, Heinrich-Heine-Universität Düsseldorf, Germany; Santos Lelita, Department of Internal Medicine, Centro Hospitalar e Universitário de Coimbra, Coimbra, Portugal; Schmeiser Tim, Krankenhaus St. Josef Hospital, Wuppertal, Germany; Serrano Benavente Belén, Department of Rheumatology, Hospital General Universitario Gregorio Marañón, Madrid, Spain; Shevtsova Tatzana; Solanki Kamal, Rheumatology Department, Waikato Hospital, Hamilton, New Zealand; Sotoca Fernàndez Jorge, Servicio de Pediatría, Mälarsjukhuset, Eskilstuna, Sweden; Sozeri Betul, Department of Pediatric Rheumatology, Ege University Faculty of Medicine, Izmir, Turkey; Stamenkovic Bojana, Institute for Prevention, Treatment and Rehabilitation of Rheumatic and Cardiovascular Diseases, Niska Banja, Serbia and Montenegro; Stebbings Simon, Department of Medicine, University of Otago, Dunedin, New Zealand; Sulli Alberto, Research Laboratory and Academic Division of Clinical Rheumatology,University of Genova, Genova, Italy; Sunderkotter Cord, Department of Dermatology, University Hospital, Münster, Germany; Sztajnbok Flavio, Division of Pediatric Rheumatology, Instituto de Puericultura e Pediatria Martagão Gesteira, Universidade Federal do Rio de Janeiro, Rio de Janeiro, Brazil; Szucs Gabriella, Department of Rheumatology, Institute of Medicine, University of Debrecen, Debrecen, Hungary; Terreri Maria T, Pediatric Rheumatology Unit, Universidade Federal de São Paulo, Sao Paulo, Brazil; Uziel Yosef, Meir Medical center, Tel Aviv University, Tel Aviv, Israel; Vacca Alessandra, Rheumatology Unit, Azienda Ospedaliero Universitaria di Cagliari, Cagliari, Italy; Valenzuela Antonia, Department of Immunology and Rheumatology, Stanford University School of Medicine, Palo Alto, USA; van den Hoogen Frank, Department of Rheumatology, Radboud University Medical Center, Nijmegen, The Netherlands; Vargas Angelica, National Institute of Cardiology Ignacio Chavez, Department of Rheumatology, Mexico City, Mexico; Veale Douglas, The Centre for Arthritis and Rheumatic Disease, Dublin Academic Medical Centre, St. Vincent's University Hospital, Dublin, Ireland; Vilela Verônica, Department of Rheumatology, Hospital Universitário Pedro Ernesto, Rio de Janeiro, Brazil; von Muhlen Carlos, Brazilian Society of Autoimmunity; Walker Ulrich, Rheumatology Department, University Hospital Basel, Basel, Switzerland; Wierzba Karol, Clinic of Internal Medicine, Connective Tissue Diseases \& Geriatrics, Gdańsk, Poland; Yavuz Sule, Istanbul Bilim University, Istanbul, Turkey; Thierry Zenone, Department of Internal Medicine, Centre Hospitalier, Valence, France. 
Corresponding author:

Francesca Ingegnoli

Division of Rheumatology, ASST Gaetano Pini

Dept. of Clinical Sciences and Community Health, Università degli Studi di Milano

P.zza Cardinal Ferrari 1, 20122 Milano, Italy

Tel: +390258296456, Fax: +390258296804

Email: francesca.ingegnoli@unimi.it 


\section{ABSTRACT}

Objectives. To canvas opinion concerning the role of non-invasive techniques in the assessment of patients with Raynaud's phenomenon (Rp) in clinical and research settings: four nailfold capillaroscopy methods (videocapillaroscopy [NVC], dermoscopy, stereomicroscopy, digital USB microscopy), four laser Doppler methods (laser Doppler flowmetry, imaging, anemometry/velocimetry, laser Speckle Contrast Analysis), thermographic imaging, and upper limb arterial Doppler ultrasound.

Methods. Emails with a link to the survey were sent to physicians from the European Scleroderma Trials and Research group (EUSTAR), the EULAR Study Group on Microcirculation in Rheumatic Diseases (SG_MC/RD) and members of the pediatric rheumatology Email board. The main descriptive analysis related to physicians looking after adult patients, with some analysis also of opinions from paediatric rheumatologists.

Results. 106 'adult physicians' responded (a response rate of 25.8\%), of whom $68.9 \%$ were European, and $81.1 \%$ practising for more than 10 years. Nineteen paediatricians responded. The most widely available technique was NVC (72.7\%). Nailfold capillaroscopy was most frequently performed by the physician him/herself, using different types of equipment relating to availability. Most rheumatologists reported high levels of appropriateness for NVC in both clinical and research settings for global assessment and differential diagnosis of Rp. Other techniques were less used.

Conclusions. Of all the different techniques, nailfold capillaroscopy was the one most used in both clinical and research settings by adult physicians, the majority of whom use NVC in their everyday practice. The low proportion of clinicians using other techniques suggests that these are currently mainly research tools, available only in specialist centres. 


\section{Key words}

Nailfold capillaroscopy, videocapillaroscopy, dermoscopy, laser Doppler flowmetry, laser Doppler imaging, anemometry/velocimetry, laser Speckle Contrast Analysis, thermographic imaging, upper limb arterial Doppler ultrasound, Raynaud's phenomenon, systemic sclerosis, connective tissue disease

Compliance with Ethical Standards:

* Disclosure of potential conflicts of interest: none

* $\quad$ Research involving human participants and/or animals: not applicable * Informed consent: not applicable

Funding statement: none 


\section{INTRODUCTION}

Raynaud's phenomenon ( $\mathrm{Rp})$ is common, with an estimated prevalence in the general population of 3 to $5 \%$ [1]. While clinical assessment and laboratory testing provide important information for the differential diagnosis between primary and secondary forms, imaging investigations are considered a valuable addition [2], in both clinical and research settings. The added value of magnified visualization of the nailfold microcirculation (capillaroscopy) is highlighted in the 2013 classification criteria for systemic sclerosis (SSc) $[3,4]$, meaning that ideally all rheumatologists should be familiar with the technique.

Different diagnostic imaging techniques may be applied in patients with Rp and SScspectrum disorders to study the structure and function of the finger microcirculation $[5,6]$. Among the available techniques, nailfold capillaroscopy is widely applied either with highly specialized equipment such as videocapillaroscopy (NVC), or simple in-office dermatoscopes. Thermographic imaging and laser Doppler techniques may also be valuable in the assessment of $\mathrm{Rp}$, but the extent of their use among specialists in clinical practice is unknown and an expert committee suggested that thermographic imaging and laser Doppler flowmetry were 'inappropriate' due to 'difficulties in implementation and questionable utility' [7]. The concurrent use of multiple techniques tends currently to be restricted to tertiary referral centers and for research purposes.

Despite growing interest in the use of non-invasive imaging techniques in the assessment of $\mathrm{Rp}$, current usage of these different techniques to assess microcirculation in Rp is unknown. We therefore surveyed physicians in specialties routinely involved in the management of $\mathrm{Rp}$. Here we report the analysis of responses from this international SUrvey on non-iNvaSive tecHniques to assess the mlcrocirculation in patients with RayNaud's phEnomenon (SUNSHINE survey). Our goal was to obtain an insight into current opinion and utilisation of the specific techniques that may be used in the 
assessment of patients with $\mathrm{Rp}$ in both clinical and research practice. Specifically, opinion regarding their potential role in screening, in clinical monitoring and as outcome measures was evaluated.

\section{METHODS}

\section{Survey Design}

The SUNSHINE survey (see Appendix 1) was designed on the basis of a review of the literature and from the contributions of experts in the field. The survey comprised 27 questions, 11 of which included basic demographic and background information regarding respondents' current practice and monitoring of $\mathrm{Rp}$. The other 16 questions focussed on the non-invasive techniques: NVC, nailfold dermoscopy, nailfold stereomicroscopy, nailfold digital USB microscopy, laser Doppler flowmetry, laser Doppler imaging, laser Doppler anemometry/velocimetry, Laser Speckled Contrast Analysis (LASCA), thermographic imaging, upper limb arterial Doppler ultrasound (US). In particular, participants were asked about their self-assessed knowledge regarding the different techniques (1 question), their current usage and the availability of the different techniques in their practice (5 questions), and their opinion as to the appropriateness of the techniques (for global assessment, differential diagnosis, and monitoring) in clinical (5 questions) and in research settings (5 questions) (see appendix 1).

\section{Survey Sample and Administration - adult physicians}

The SUNSHINE survey was devised to evaluate opinions of the members of the European League Against Rheumatism (EULAR) Study Group on Microcirculation in Rheumatic 
diseases (SG_MC/RD) and the EULAR Scleroderma Trials and Research (EUSTAR), using their 2015 mailing lists. It was conducted between October and December 2015 using an internet-based program (Google forms). A call for survey completion was sent after nearly one month. At the beginning of the survey participants were all explicitly asked if they were willing to complete the survey and informed that their consent and the completion of the survey would have permitted to listed them in the manuscript as part of SUNSHINE Study Group unless denied.

From the 456 email addresses, we excluded all those which were not specifically namedpersons and duplicates, giving a total sample of 420 (Figure 1-A). Of the 120 responses, 9 were from individuals who responded twice, 4 were ineligible (2 respondents reported they were not sufficiently skilled to participate in the survey, as per their response to Question 1, and 2 were paediatricians), and 1 questionnaire was returned blank.

All the 106 eligible responders completed the questionnaire: no partial questionnaires were returned due to the design of the survey in which skipping items were not permitted. Of the 309 non-respondents, 5 were estimated ineligible from information regarding eligibility from web-based public data (Figure 1-A).

This yielded a raw eligibility [(305+106)/420] 97.8\%. Response rate was [106/(106+305)] $25.8 \%$, the cooperation rate was $[106 /(106+1)] 99.1 \%$. Outcome rates were calculated according to the American Association for Public Opinion Research 2015 [8].

The distributions of variables collected in the survey were summarized by means of absolute numbers and percentages and plotted by bar charts.

\section{Survey Substudy - paediatricians}

To provide information regarding the management of paediatric $\mathrm{Rp}$, the survey was extended into a substudy involving paediatric rheumatologists. The same internet-based 
survey was sent to a paediatric rheumatology email board. As this mailing list was not sufficiently detailed in terms of number and characteristics of the email addresses/members, outcome rates were not calculated and the substudy was managed separately. Of 20 respondents, 3 were ineligible because the participants reported they were not sufficiently skilled (Question 1). The 2 paediatricians previously excluded from the EULAR SG_MC/RD and EUSTAR mailing lists were added to this substudy (Figure 1B).

\section{RESULTS}

\section{Demographic characteristics}

Among specialists taking care of adult patients, the characteristics of the respondents and non-respondents are shown in Figure 2. Respondents were mainly rheumatologists (83.0\%) in University hospitals (90.6\%) in European countries (68.9\%) and were mainly practicing for more than 10 years (81.1\%).

More than $50 \%$ of the respondents reported that they looked after $>30$ patients per year with primary and/or secondary Rp. The area of specialization was deemed relevant to the survey, but the number of participants with specializations other than rheumatology turned out to be too low to allow proper analysis (Figure 2). The following analysis is confined to rheumatologists' opinions (88 respondents), to ensure uniformity.

eTable 1 shows how often rheumatologists monitor their patients with primary and secondary $\mathrm{Rp}$ in relation to the number of patients under their care per year. Overall, patients with primary or secondary Rp are monitored regularly, but the frequency of visits is highly variable. 


\section{Overall view}

As shown in figure 3A, the nailfold capillaroscopic techniques were those associated with the highest levels of self-assessed knowledge.

Specifically, for NVC the level of knowledge was judged as either good or satisfactory in $90.9 \%(80 / 88)$. NVC is also the most often performed (60.2\% "Routinely - more than once/month"), performed by rheumatologists themselves (61.4\%) and routinely available in the place of work (72.7\%) (Figure 4). In contrast, fewer than $50 \%$ of rheumatologists reported a good or satisfactory level of knowledge of techniques other than capillaroscopy. Regarding use and availability, very few rheumatologists (fewer than $10 \%$ ) sometimes or routinely used any of the techniques other than NVC, and these were seldom available (less than 30\%) either at the workplace or in another hospital, except for dermoscopy and upper limb arterial Doppler ultrasound (over 50\% among rheumatologists) (Figure 4).

\section{Clinical and research settings}

Respondents were asked to self-assess their knowledge for each technique. Only respondents whose self-assessed level of knowledge was at least good or satisfactory were considered. Therefore this analysis included a different number of respondents for each technique.

Clinical setting. More than $85 \%$ of rheumatologists judged all nailfold capillaroscopy techniques as 'appropriate' or 'very appropriate' in the global assessment, differential diagnosis, and monitoring of primary and Rp secondary to either SSc or other connective tissue diseases (Figure 5). The use of NVC was consistently assessed as appropriate or very appropriate by more than $95 \%$ of respondents, and the use of nailfold dermoscopy, stereomicroscopy, and USB microscopy by more than $88 \%$. For thermography and upper limb arterial Doppler US, only their use for the global assessment of Rp was judged 
appropriate or very appropriate (respectively $76.5 \%$ and $67.6 \%$ ), while for all the other indications proportions were substantially lower (range 13.3\%-35.3\% and 38.9\%-51.3\% respectively) (Supplementary materials, eTable 2).

Research setting. Only NVC was consistently judged as appropriate or very appropriate in the global assessment (98.7\%), differential diagnosis (98.7\%) and monitoring primary and secondary Rp either in SSc or other connective tissue diseases (87.3\%, 98.7\% and 87.2\%

respectively) (Figure 5). Opinions about the use of nailfold dermoscopy, stereomicroscopy, and USB microscopy were less uniform, and heterogeneous answers were observed for thermography and Doppler US (Supplementary materials, eTable 2).

\section{Survey Substudy on Paediatric Rheumatologists}

The characteristics of the respondents among paediatric physicians are shown in Figure 2. In the online appendix, eTable3 summarizes how often paediatric rheumatologists monitor Rp.

As shown in Figure 3B, both NVC and dermoscopy have the highest levels of selfassessed knowledge (good or satisfactory in $72.2 \%$ and $66.7 \%, 13 / 18-12 / 18$, respectively). However, only dermoscopy was performed sometimes or routinely by paediatric rheumatologists themselves, and available at workplace in more than $50 \%$ of the responders (Supplementary materials, eTable 4).

Among paediatric rheumatologists whose opinion was taken into account for analysis (good or satisfactory knowledge range 33.3\%-72.2\%, 6/18 - 13/18 all the nailfold capillaroscopy techniques showed consistent ratings of appropriateness (appropriate or very appropriate $>80 \%$ ) for each item both in clinical and research settings (eTable 5). Ratings about the techniques other than capillaroscopy were derived from a minority of the responders (eTable 6) range 5.5\% - 33.3\%, 1/18 - 6/18) and were inconsistent. 


\section{DISCUSSION}

The SUNSHINE survey gives a real-life overview about knowledge and availability of noninvasive techniques to assess the microcirculation among rheumatologists who take care of patients with $\mathrm{Rp}$, and therefore provides useful background information for clinicians and researchers writing management guidelines or planning collaborative studies.

Our data show that the level of self-assessed knowledge varies between different techniques. Among adult rheumatologists, capillaroscopy was most widely used, probably because rheumatologists are especially interested in the early differential diagnosis between primary and secondary Rp. The widespread us of capillaroscopy is not surprising since the value of the morphologic assessment of nailfold capillary abnormalities has long been recogniszed, evidenced by the proposal for classification of $\mathrm{Rp}$ in 1992 [9], and recently further corroborated by the inclusion of abnormal nailfold capillaries into the 2013 classification criteria for SSc [3]. The level of knowledge and availability of NVC was higher than other capillaroscopic techniques. Studies comparing different capillaroscopic techniques are sparse and limited to NVC, dermoscopy and stereomicroscopy in patients with SSc-spectrum disorders [10-12]. A clinician's choice of technique is likely to be guided by her/his personal experience. Rheumatologists tend to favour NVC, whereas dermatologists may prefer to use dermoscopy (data from four respondents, not shown). This applies both in research and clinical settings.

Regarding the techniques other than capillaroscopy, the low numbers of evaluable responses (i.e. responses from individuals knowledgeable in the technique) combined with the inconsistent opinions about the appropriateness of use suggest that these are currently little used and confined to specialist centers. Data from paediatric rheumatologists were influenced by the small sample size and so few conclusions can be drawn. However, it can be seen that NVC and dermoscopy are the techniques most used by paediatric 
rheumatologists and these results underscore the importance of recent efforts to develop recommendations for assessment and monitoring of $\mathrm{Rp}$ in children [13].

Our survey has several limitations. First, the nonresponse bias may have affected the representativeness of these data. Our response rate was low as expected for internet surveys conducted among physicians and comparable with similar studies [14]. Second, although respondents were from 115 different centers from all over the world, the majority of respondents were rheumatologists from Europe and university hospitals and so results may not be generalizable to other countries/settings/specialties. However, since EUSTAR centers are those mainly represented in this survey, the results are representative of those centres likely to be participating in multicentre research projects initiated by EUSTAR and EULAR study group on microcirculation (SG_MC/RD). Finally, data were mainly obtained from self-assessment and this subjectivity reflects attitudes and perception from specialists' experience.

Despite these limitations, the survey benchmarks current clinical and research practice in the assessment of the microcirculation. We have shown that capillaroscopy, particularly NVC, is the technique with which the rheumatologists are most familiar, and most widely used in everyday practice. Knowledge and experience with other non-invasive imaging techniques is extremely limited. This finding needs to be taken into account when developing recommendations on the assessment of the microcirculation in patients with $\mathrm{Rp}$ in both clinical and research settings. Our findings suggest that if objective measures of finger temperature and blood flow (i.e. thermography, laser Doppler methods) are to be proposed as outcome measures of disease progression or treatment response in multicentre trials, then clinician education and training in these different methods is warranted, as is done by the EULAR courses on capillaroscopy which include these different methods (www.eular.org-education). 


\section{REFERENCES}

1. Garner R, Kumari R, Lanyon P, Doherty M, Zhang W (2015) Prevalence, risk factors and associations of primary Raynaud's phenomenon: systematic review and meta-analysis of observational studies. BMJ open 5 (3):e006389. doi:10.1136/bmjopen-2014-006389

2. Wigley FM, Flavahan NA (2016) Raynaud's Phenomenon. N Engl J Med 375 (6):556565. doi:10.1056/NEJMra1507638

3. van den Hoogen F, Khanna D, Fransen J, Johnson SR, Baron M, Tyndall A, MatucciCerinic M, Naden RP, Medsger TA, Jr., Carreira PE, Riemekasten G, Clements PJ, Denton CP, Distler O, Allanore Y, Furst DE, Gabrielli A, Mayes MD, van Laar JM, Seibold JR, Czirjak L, Steen VD, Inanc M, Kowal-Bielecka O, Muller-Ladner U, Valentini G, Veale DJ, Vonk MC, Walker UA, Chung L, Collier DH, Ellen Csuka M, Fessler BJ, Guiducci S, Herrick A, Hsu VM, Jimenez S, Kahaleh B, Merkel PA, Sierakowski S, Silver RM, Simms RW, Varga J, Pope JE (2013) 2013 classification criteria for systemic sclerosis: an American college of rheumatology/European league against rheumatism collaborative initiative. Ann Rheum Dis 72 (11):1747-1755. doi:annrheumdis-2013-204424 [pii]

\subsection{6/annrheumdis-2013-204424}

4. van den Hoogen F, Khanna D, Fransen J, Johnson SR, Baron M, Tyndall A, MatucciCerinic M, Naden RP, Medsger TA, Jr., Carreira PE, Riemekasten G, Clements PJ, Denton CP, Distler O, Allanore Y, Furst DE, Gabrielli A, Mayes MD, van Laar JM, Seibold JR, Czirjak L, Steen VD, Inanc M, Kowal-Bielecka O, Muller-Ladner U, Valentini G, Veale DJ, Vonk MC, Walker UA, Chung L, Collier DH, Csuka ME, Fessler BJ, Guiducci S, Herrick A, Hsu VM, Jimenez S, Kahaleh B, Merkel PA, Sierakowski S, Silver RM, Simms RW, Varga J, Pope JE (2013) 2013 classification criteria for systemic sclerosis: an American College of Rheumatology/European League against Rheumatism collaborative initiative. Arthritis Rheum 65 (11):2737-2747. doi:10.1002/art.38098 
5. Smith V, Beeckman S, Herrick AL, Decuman S, Deschepper E, De Keyser F, Distler O, Foeldvari I, Ingegnoli F, Muller-Ladner U, Riccieri V, Riemekasten G, Sulli A, Voskuyl A, Cutolo M, microcirculation Esgo (2016) An EULAR study group pilot study on reliability of simple capillaroscopic definitions to describe capillary morphology in rheumatic diseases. Rheumatology (Oxford) 55 (5):883-890. doi:10.1093/rheumatology/kev441

6. Dinsdale G, Herrick A (2014) Vascular diagnostics for Raynaud's phenomenon. Journal of Vascular Diagnostics 4 (2):127-139

7. Maverakis E, Patel F, Kronenberg DG, Chung L, Fiorentino D, Allanore Y, Guiducci S, Hesselstrand R, Hummers LK, Duong C, Kahaleh B, Macgregor A, Matucci-Cerinic M, Wollheim FA, Mayes MD, Gershwin ME (2014) International consensus criteria for the diagnosis of Raynaud's phenomenon. J Autoimmun 48-49:60-65. doi:S08968411(14)00023-7 [pii] 10.1016/j.jaut.2014.01.020

8. 2015. AAfPOR (2015) Standard Definitions: Final Dispositions of Case Codes and Outcome Rates for Surveys. AAPOR, 8th edition edn.,

9. LeRoy EC, Medsger TA, Jr. (1992) Raynaud's phenomenon: a proposal for classification. Clin Exp Rheumatol 10 (5):485-488

10. Hughes M, Moore T, O'Leary N, Tracey A, Ennis H, Dinsdale G, Murray A, Roberts C, Herrick AL (2015) A study comparing videocapillaroscopy and dermoscopy in the assessment of nailfold capillaries in patients with systemic sclerosis-spectrum disorders. Rheumatology (Oxford) 54 (8):1435-1442. doi:10.1093/rheumatology/keu533

11. Mazzotti NG, Bredemeier M, Brenol CV, Xavier RM, Cestari TF (2014) Assessment of nailfold capillaroscopy in systemic sclerosis by different optical magnification methods. Clin Exp Dermatol 39 (2):135-141. doi:10.1111/ced.12254

12. Dogan S, Akdogan A, Atakan N (2013) Nailfold capillaroscopy in systemic sclerosis: is there any difference between videocapillaroscopy and dermatoscopy? Skin Res Technol 19 (4):446-449. doi:10.1111/srt.12067 
13. Pain CE, Constantin T, Toplak N, Moll M, Iking-Konert C, Piotto DP, Aktay Ayaz N, Nemcova D, Hoeger PH, Cutolo M, Smith V, Foeldvari I, Paediatric Rheumatology European Society Juvenile Scleroderma Working G (2016) Raynaud's syndrome in children: systematic review and development of recommendations for assessment and monitoring. Clin Exp Rheumatol 34 Suppl 100 (5):200-206

14. Cunningham CT, Quan H, Hemmelgarn B, Noseworthy T, Beck CA, Dixon E, Samuel S, Ghali WA, Sykes LL, Jette N (2015) Exploring physician specialist response rates to web-based surveys. BMC medical research methodology 15:32. doi:10.1186/s12874-0150016-Z 
Figure 1. Flowchart of SUNSHINE survey in medical professionals who take care of adult patients (A) and children (B).

A.

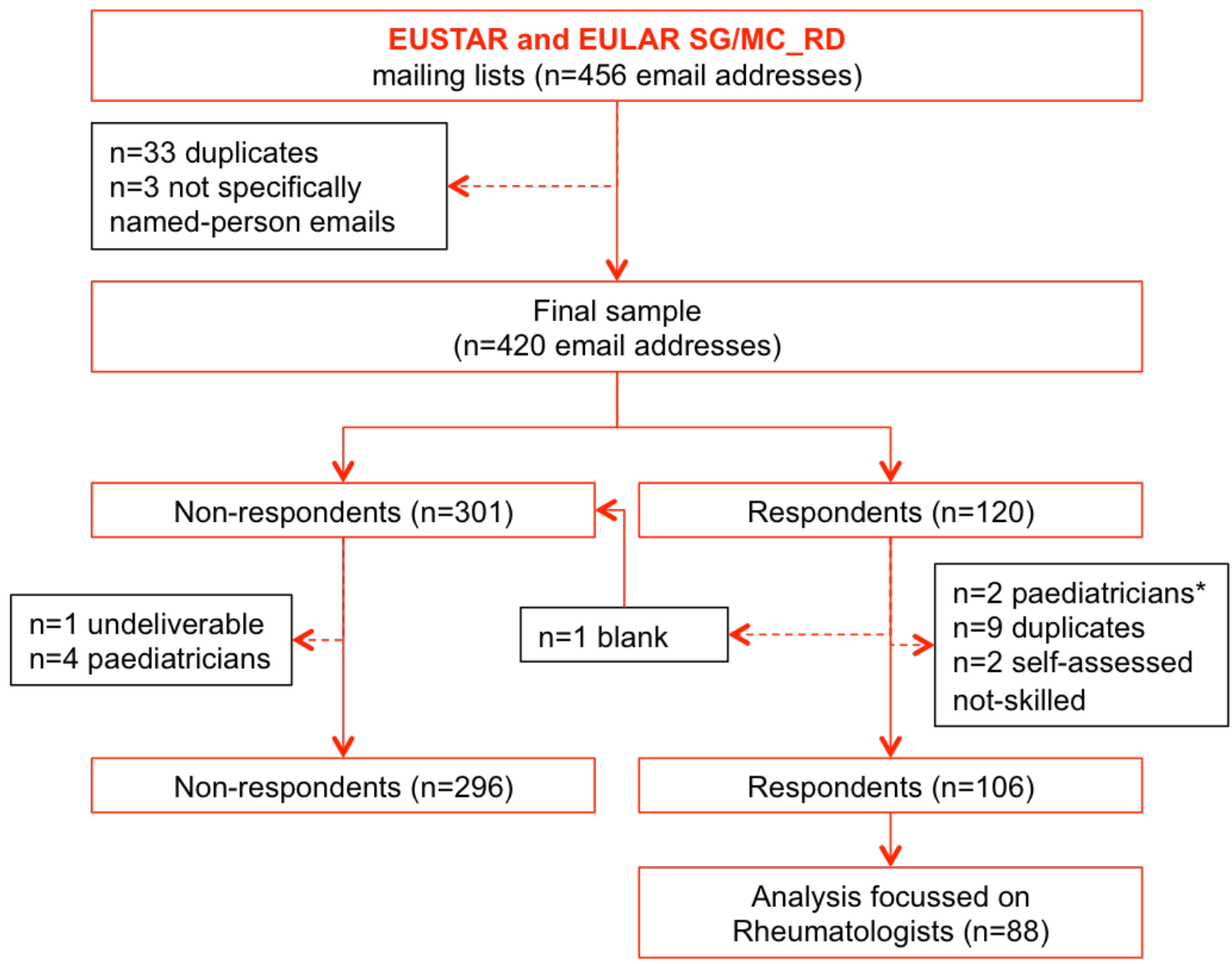

B.

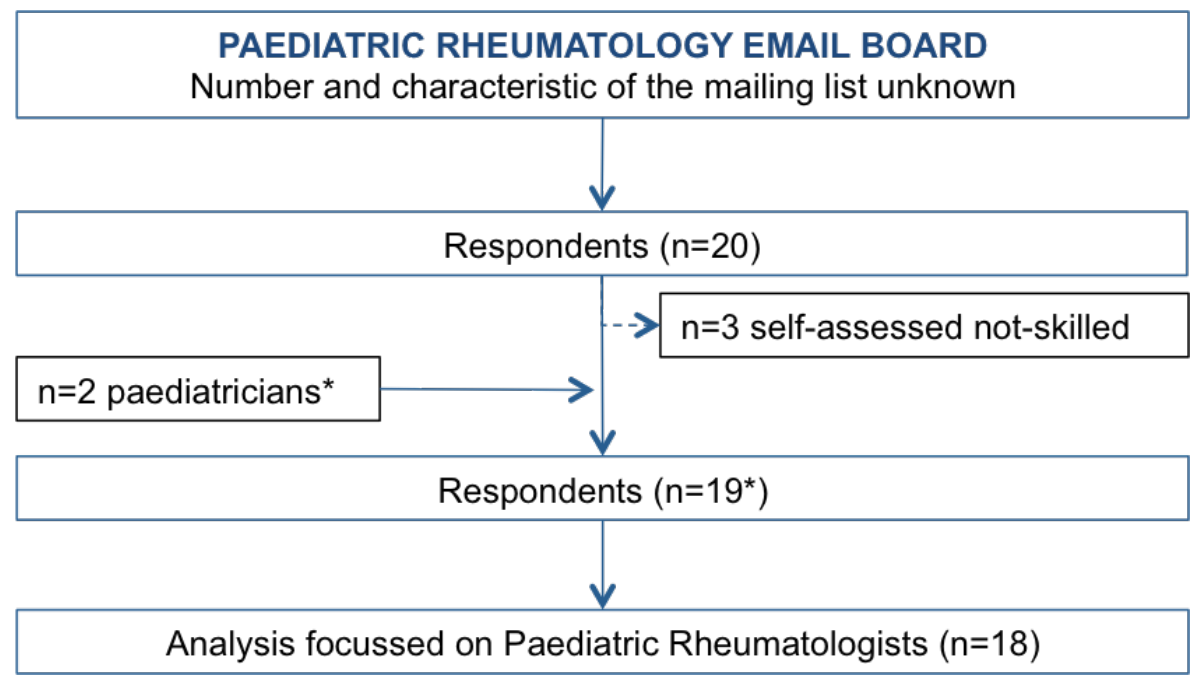


*2 paediatricians from the EUSTAR and EULAR SG/MC_RD were included in the final analysis focused on paediatric opinions. 
Figure 2. Characteristics of respondents and non-respondents by international representation $(A)$, work setting $(B)$, and primary speciality $(C)$.

A.

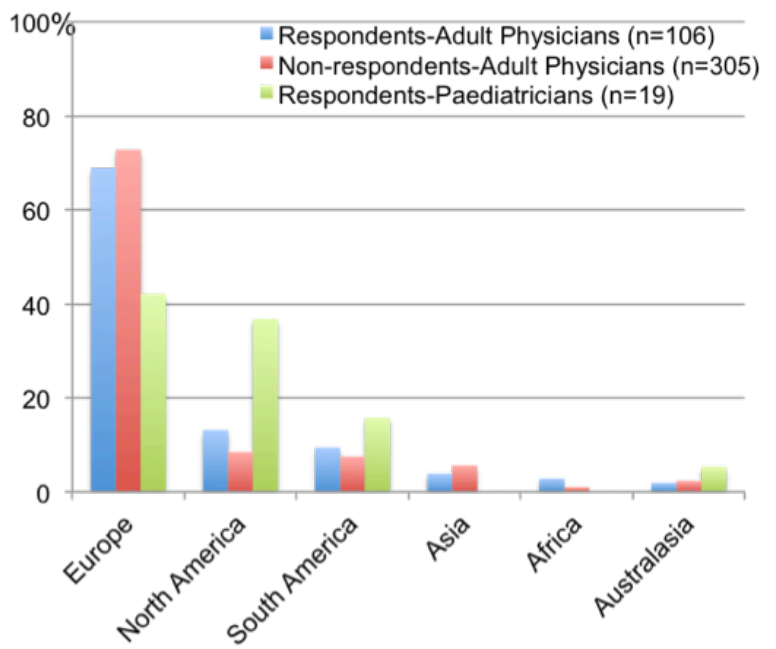

C.

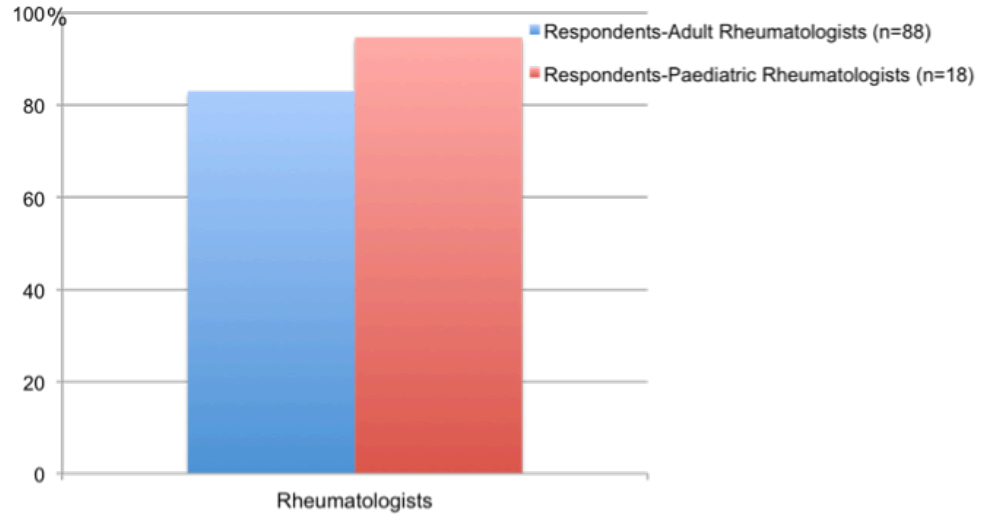

B.

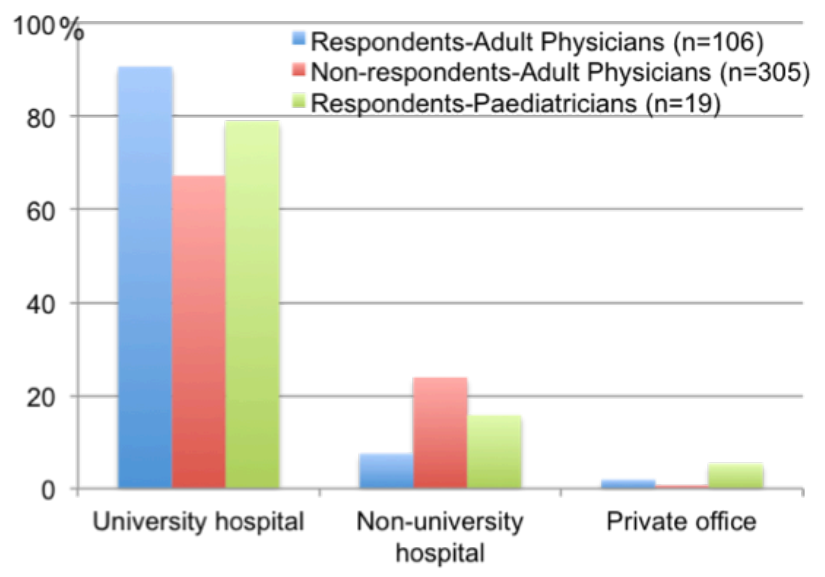

N.A. not available.

Other specialities among respondents: 9 Internal medicine, 4 Dermatology, 2 Immunology,

1 Cardiology, 1 Internal Medicine and Angiology, 1 Internal Medicine and Immunology; non-respondents: 21 Internal Medicine, 16 Dermatology, 4 Immunology, 4 Angiology, 1 Gastroenterology, 1 Epidemiology, 1 Psichology, 1 Biology, 1 Biostatistician, 2 Nurses; Paediatricians: 1 Immunology. 
Figure 3. The self-assessed level of knowledge on different techniques by adult rheumatologists $(n=88)(A)$ and paediatric rheumatologists $(n=18)(B)$.

A.

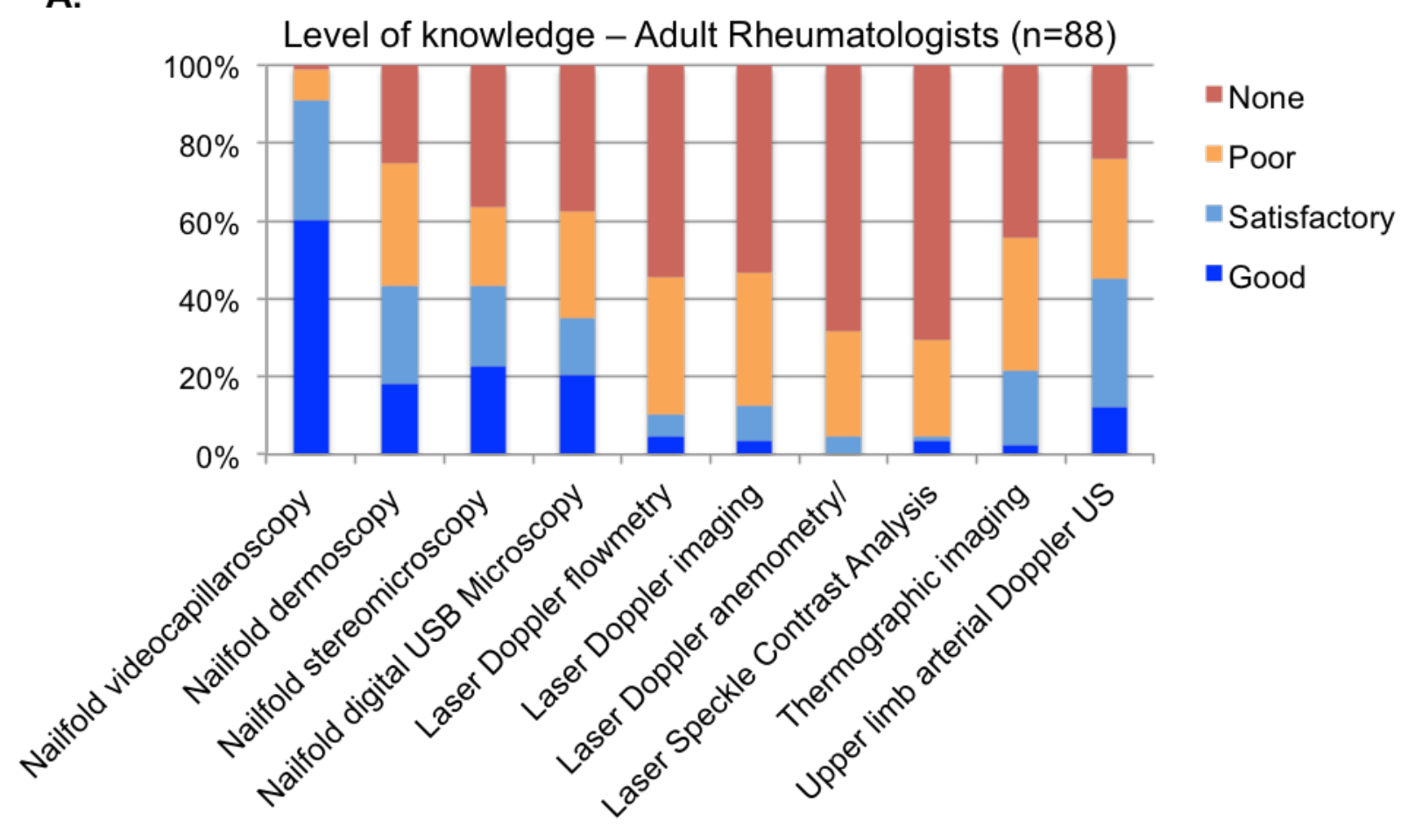

B.

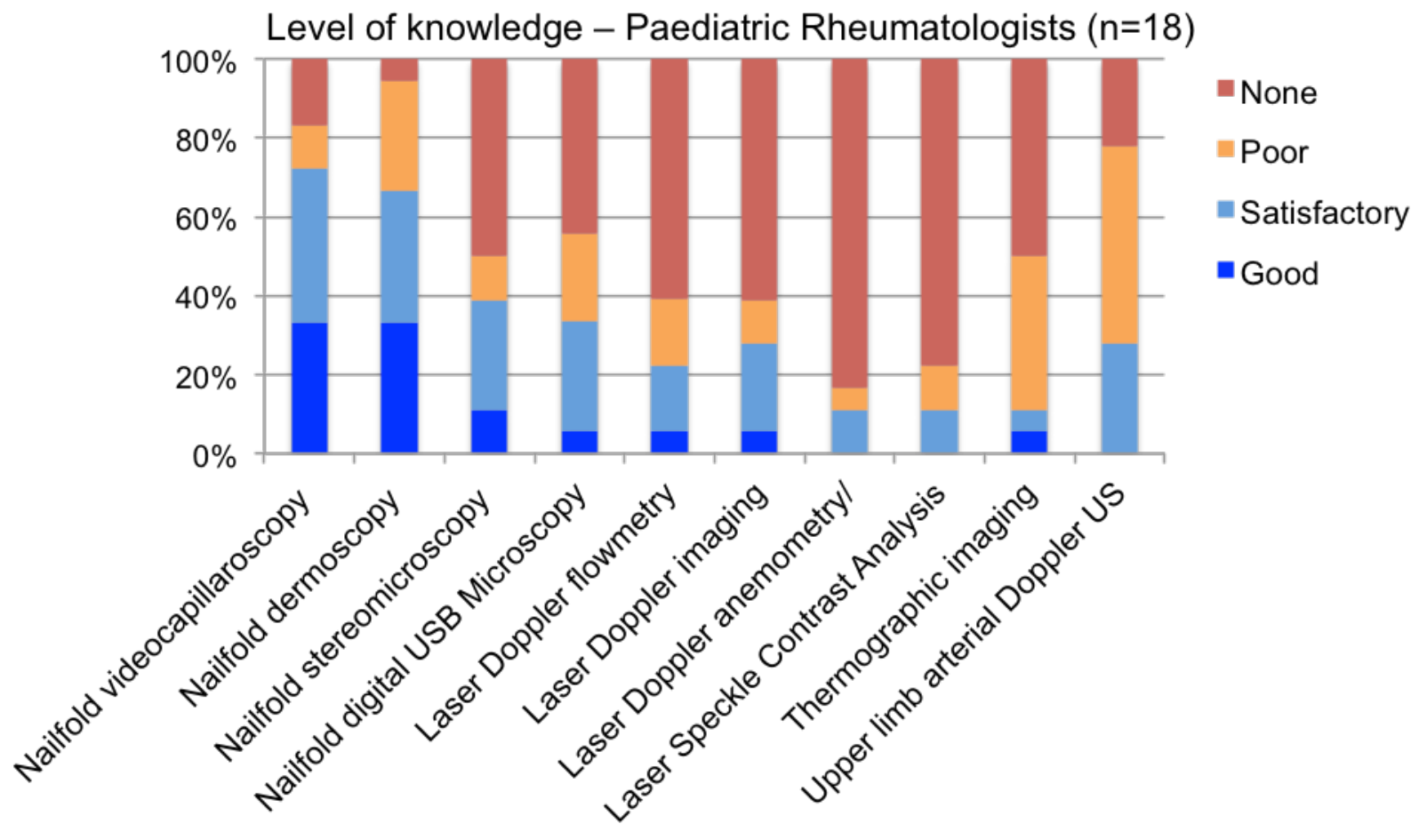


Figure 4. Overall view on the real-world usage and availability of non-invasive techniques to assess the microcirculation in patients with Raynaud's phenomenon.
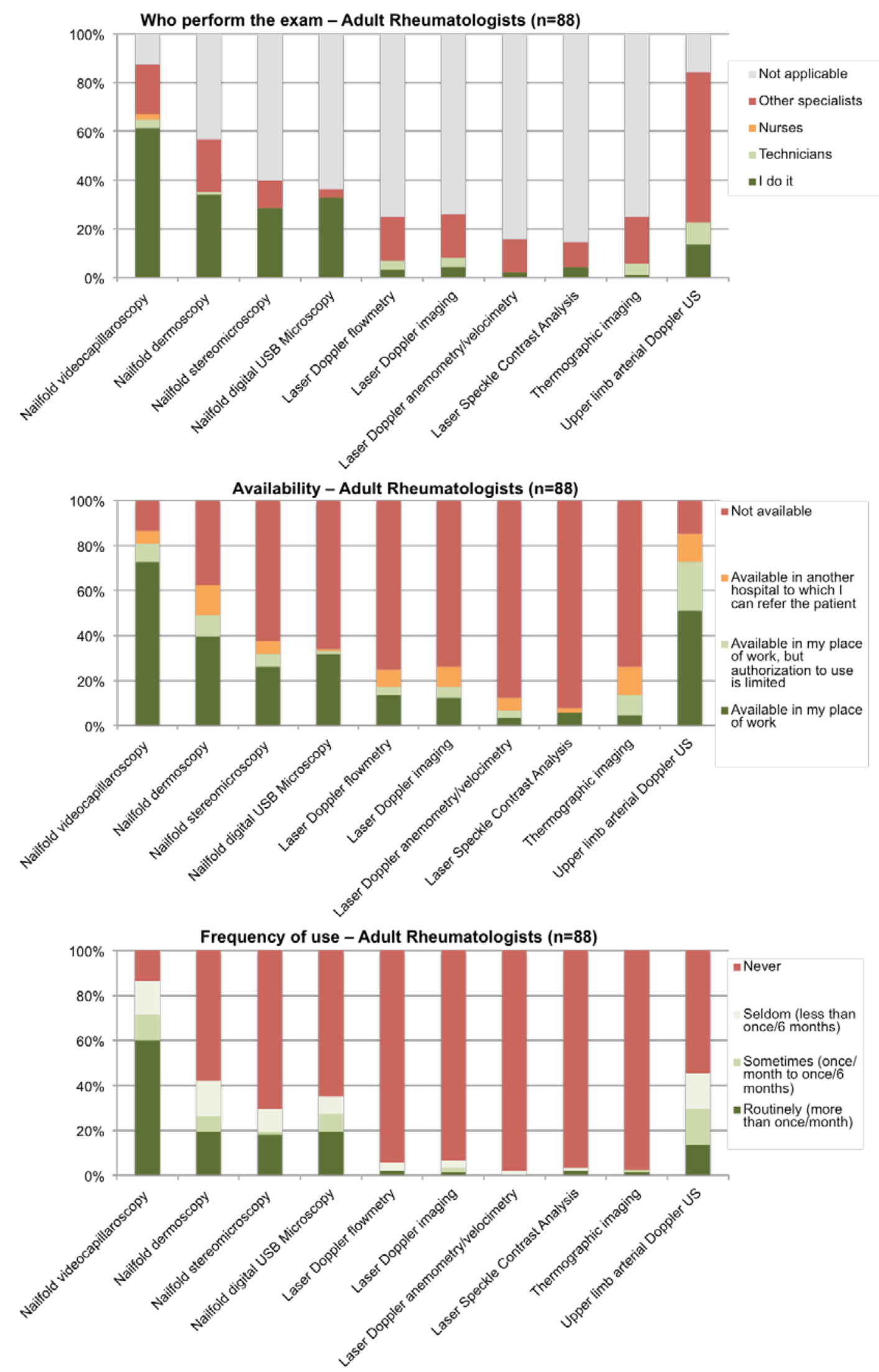
Figure 5. Opinion of adult rheumatologists on the appropriateness of use of nailfold capillaroscopy techniques in clinical practice and in a research setting.

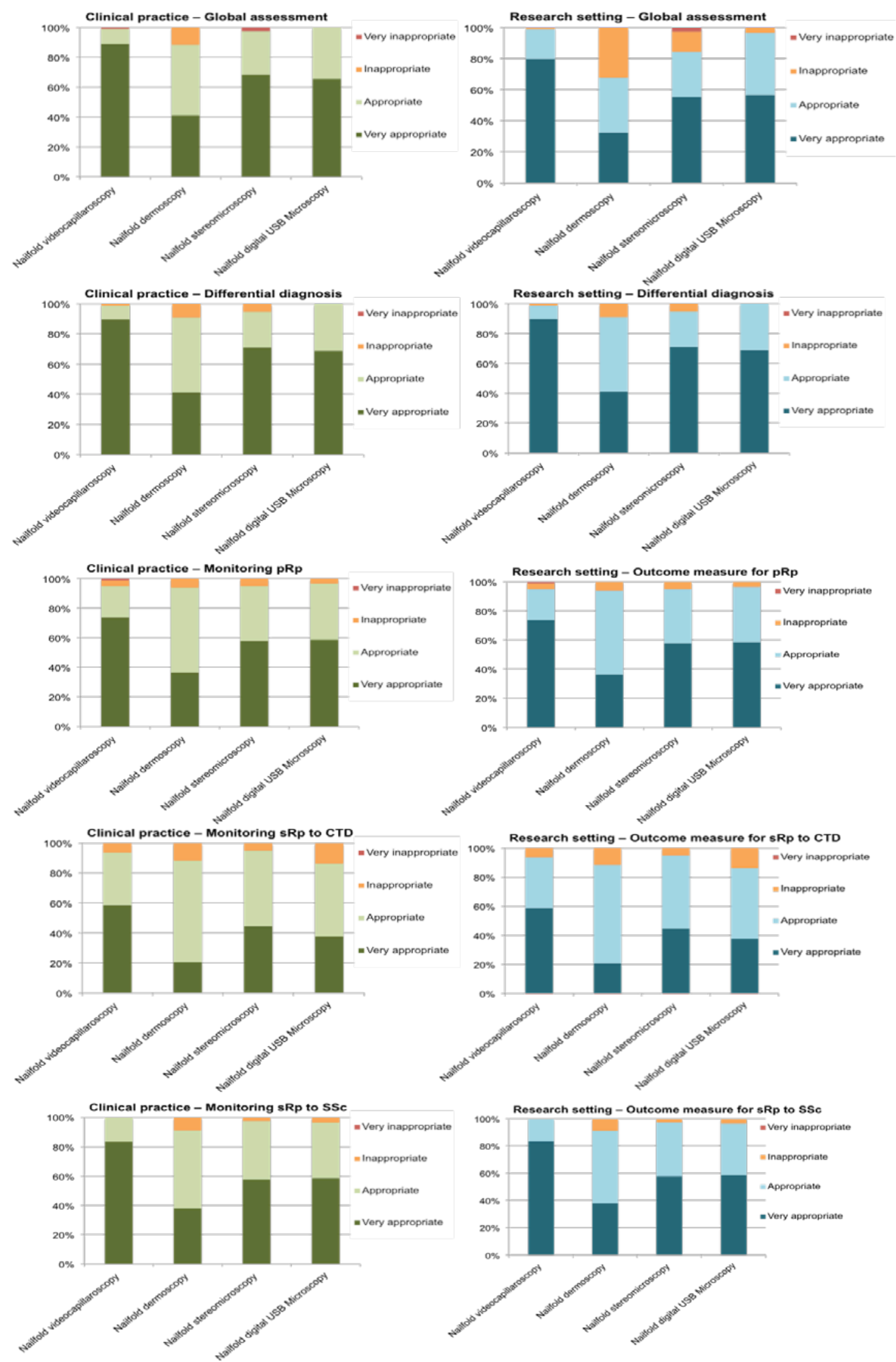




\section{Supplementary Online Content}

Appendix 1. Questions of the SUrvey on non-iNvaSive tecHniques to assess the mIcrocirculation in patients with RayNaud's phEnomenon (SUNSHINE) survey.

eTable 1. Summary of how often rheumatologists taking care of adults monitor their patients with primary and secondary Raynaud's phenomenon in relation to the number of patients under their care per year.

eTable 2. Results from rheumatologists take care of adults on the role of imaging techniques other than capillaroscopy in the management of $\mathrm{Rp}$ in clinical practice and research setting.

eTable 3. Summary of how often paediatric rheumatologists monitor their patients with primary and secondary Raynaud's phenomenon in relation to the number of patients under their care per year.

eTable 4. Overall view on the real-world usage and availability of imaging techniques by paediatric rheumatologists.

eTable 5. Results from paediatric rheumatologists on the role of capillaroscopic techniques in the management of Rp in clinical practice $(A)$ and research setting $(B)$.

eTable 6. Results from paediatric rheumatologists on the role of imaging techniques other than capillaroscopy in the management of $\mathrm{Rp}$ in clinical practice and research setting. 
Appendix 1. Questions of the SUrvey on non-iNvaSive tecHniques to assess the mIcrocirculation in patients with RayNaud's phEnomenon (SUNSHINE) survey.

\section{Demographic Questions}

How many years have you been practicing as a clinician?

$1-10 \quad 11-20 \quad 21-30 \quad>30$

Which region of the world do you work in?

North America South America Europe Asia Australia Africa

What best describes your predominant type of practice?

Private office Non-university hospital University hospital

What is your area of specialization?

Rheumatology Dermatology Angiology Vascular Surgery Cardiology

Pulmonology Other

How many patients with primary Raynaud's phenomenon (including both new diagnosis and follow-up) do you see each year?

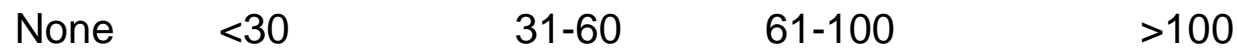

How often do you usually monitor the microcirculation in patients with primary Raynaud's phenomenon after the first assessment?

Never

Only if required on the basis of clinical progression

Once, independently of clinical progression

Periodically, independently of clinical progression (less than once a year)

Periodically, independently of clinical progression (twice a year)

Periodically, independently of clinical progression (more than twice a year) 
How many patients with Raynaud's phenomenon secondary to connective tissue diseases other than systemic sclerosis (new diagnosis and follow-up) do you see each year?

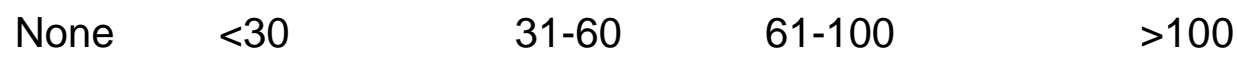

How often do you usually monitor the microcirculation in patients with Raynaud's phenomenon secondary to connective tissue diseases other than systemic sclerosis after the first assessment?

Never

Only if required on the basis of clinical progression

Once, independently of clinical progression

Periodically, independently of clinical progression (less than once a year)

Periodically, independently of clinical progression (twice a year)

Periodically, independently of clinical progression (more than twice a year)

How many patients with Raynaud's phenomenon secondary to systemic sclerosis (new diagnosis and follow-up) do you see each year?

$\begin{array}{llll}\text { None } \quad<30 & 31-60 & 61-100 & >100\end{array}$

How often do you usually monitor the microcirculation in patients with Raynaud's phenomenon secondary to systemic sclerosis after the first assessment?

Never

Only if required on the basis of clinical progression

Once, independently of clinical progression

Periodically, independently of clinical progression (less than once a year)

Periodically, independently of clinical progression (twice a year)

Periodically, independently of clinical progression (more than twice a year) 
Overview of the techniques

The following questions aim to evaluate knowledge and availability of different techniques to assess microcirculation in your practice.

Please familiarize yourself with all the items on this page before answering to ensure the similarities and differences are noted.

How would you define the level of your knowledge of the following techniques?

Nailfold videocapillaroscopy

Nailfold dermoscopy

Nailfold stereomicroscopy

Nailfold USB digital microscopy

Laser Doppler flowmetry

Laser Doppler imaging

Laser Doppler anemometry/velocimetry

Laser Speckle Contrast Analysis (LASCA)

Thermographic imaging

Upper limb arterial Doppler ultrasound

$\begin{array}{ll}1 & 2 \\ \text { None } & \text { Poor } \\ \square & \square \\ \square & \square \\ \square & \square \\ \square & \square \\ \square & \square \\ \square & \square \\ \square & \square \\ \square & \square \\ \square & \square \\ \square & \square\end{array}$

$\begin{array}{ll}3 & 4 \\ \text { Satisfactory } & \text { Good } \\ \square & \square \\ \square & \square \\ \square & \square \\ \square & \square \\ \square & \square \\ \square & \square \\ \square & \square \\ \square & \square \\ \square & \square \\ \square & \square\end{array}$

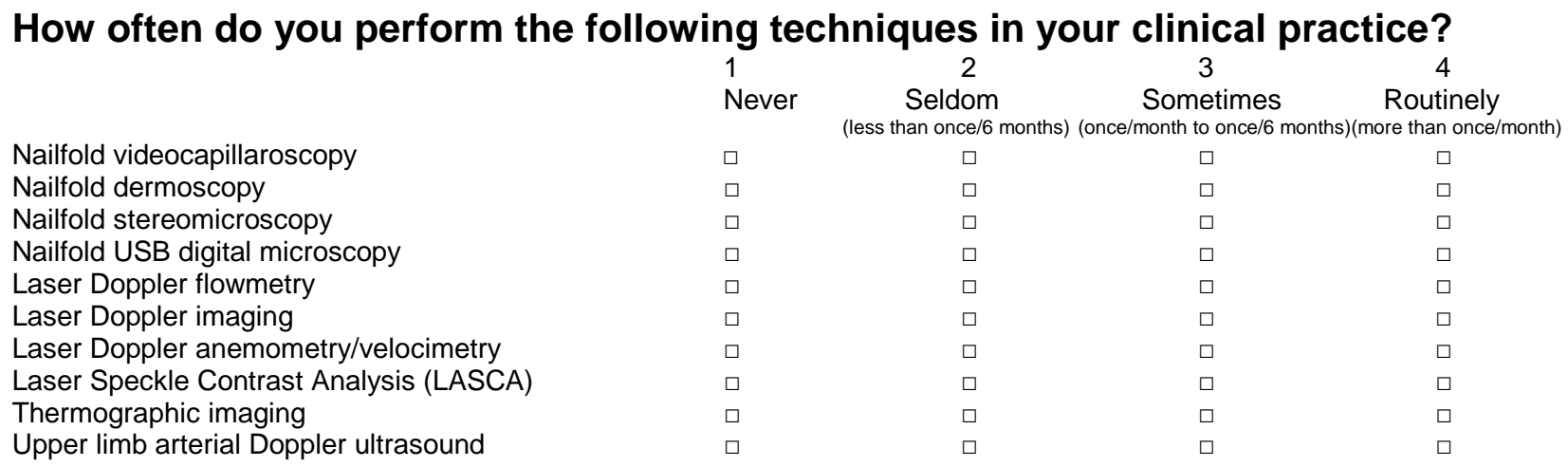

Are the following techniques available in your practice?

Not Available in my

available
Available in another Available in my hospital to which I place of work, but can refer the patient authorization to use is limited

Nailfold videocapillaroscopy

Nailfold dermoscopy

Nailfold stereomicroscopy

Nailfold USB digital microscopy

Laser Doppler flowmetry

Laser Doppler imaging

Laser Doppler anemometry/velocimetry

Laser Speckle Contrast Analysis (LASCA)

Thermographic imaging

Upper limb arterial Doppler ultrasound 
Which is the level of accessibility of the following technologies in your practice? (i.e.: the technology is available but authorization to use is limited for any reason)

$\begin{array}{cccc}1 & 2 & 3 & 4 \\ \text { Not accessible } & \text { Seldom } & \text { Sometimes } & \begin{array}{c}\text { Routinely } \\ \text { (less than once/6 months) }\end{array} \\ & \text { (once/month to once/6 } & \text { months)(more than once/month) }\end{array}$

Nailfold videocapillaroscopy

Nailfold dermoscopy

Nailfold stereomicroscopy

Nailfold USB digital microscopy

Laser Doppler flowmetry

Laser Doppler imaging

Laser Doppler anemometry/velocimetry

Laser Speckle Contrast Analysis (LASCA)

Thermographic imaging

Upper limb arterial Doppler ultrasound

If one or more of these techniques are available, who performs the exam?

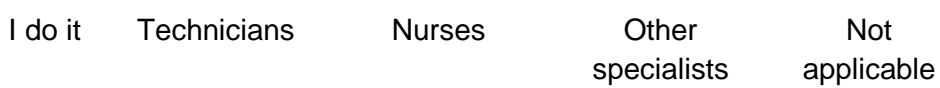

Nailfold videocapillaroscopy

Nailfold dermoscopy

Nailfold stereomicroscopy

Nailfold USB digital microscopy

Laser Doppler flowmetry

Laser Doppler imaging

Laser Doppler anemometry/velocimetry

Laser Speckle Contrast Analysis (LASCA)

Thermographic imaging

Upper limb arterial Doppler ultrasound $\square$

$\square$

$\square$

$\square$

$\square$

$\square$

$\square$

$\square$

$\square$

$\begin{array}{llll}\square & \square & \square & \square \\ \square & \square & \square & \square \\ \square & \square & \square & \square \\ \square & \square & \square & \square \\ \square & \square & \square \\ \square & \square & \square & \square \\ \square & \square & \square & \square \\ \square & \square & \square & \square \\ \square & \square & \square & \square \\ \square & \square & \square & \square\end{array}$

Are there other techniques that you use, or would consider using, in the assessment of Raynaud's phenomenon?

$\square$ Yes $\quad \square$ No

If yes, please specify and explain why 


\section{Clinical Setting}

The following questions are designed to evaluate the appropriateness of different techniques to assess the microcirculation in Raynaud's phenomenon in a routine clinical setting (i.e. diagnosis and monitoring).

How would you rate the appropriateness of the following items for the global assessment of microcirculation in primary and secondary Raynaud's phenomenon in a routine clinical setting?

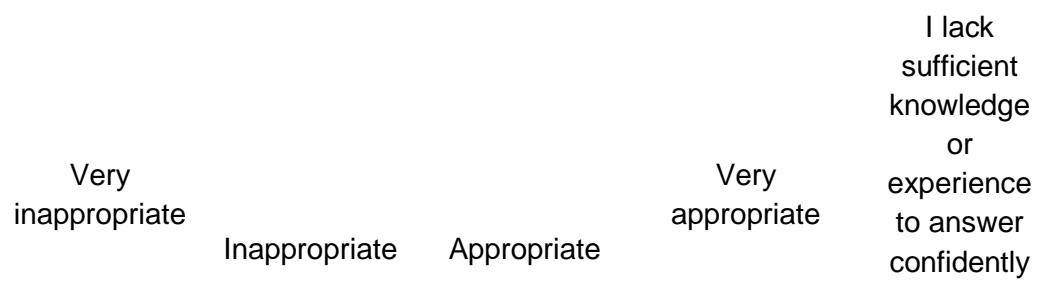

Nailfold videocapillaroscopy

Nailfold dermoscopy

Nailfold stereomicroscopy

Nailfold USB digital microscopy

Laser Doppler flowmetry

Laser Doppler imaging

Laser Doppler anemometry/velocimetry

Laser Speckle Contrast Analysis (LASCA)

Thermographic imaging

Upper limb arterial Doppler ultrasound

How would you rate the appropriateness of the following items for the differential diagnosis of primary and secondary Raynaud's phenomenon in a routine clinical setting? 
Nailfold videocapillaroscopy

Nailfold dermoscopy

Nailfold stereomicroscopy

Nailfold USB digital microscopy

Laser Doppler flowmetry

Laser Doppler imaging

Laser Doppler anemometry/velocimetry

Laser Speckle Contrast Analysis (LASCA)

Thermographic imaging

Upper limb arterial Doppler ultrasound

\section{$\square$}

口

口

口

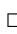

口

口

口

口

口

\section{$\square$}

\section{口}

$\square$

$\square$

$\square$

$\square$

$\square$

$\square$

$\square$

$\square$ $\square$
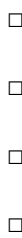

$\square$

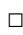

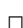

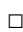

$\square$

How would you rate the appropriateness of the following items for monitoring primary Raynaud's phenomenon over time in clinical settings?

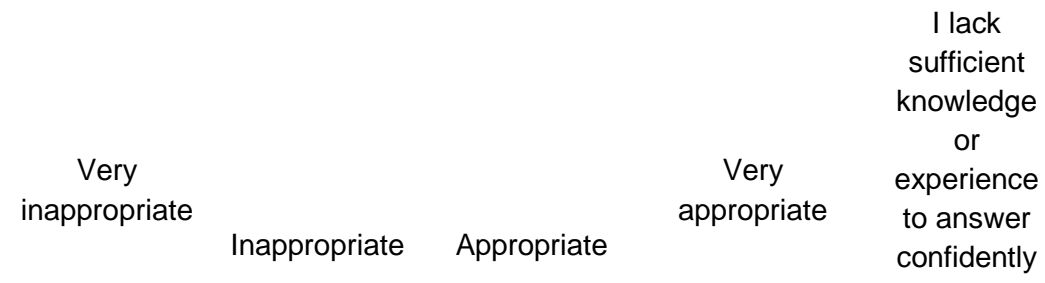

Nailfold videocapillaroscopy

Nailfold dermoscopy

Nailfold stereomicroscopy

Nailfold USB digital microscopy

Laser Doppler flowmetry

Laser Doppler imaging

Laser Doppler anemometry/velocimetry

Laser Speckle Contrast Analysis (LASCA)

Thermographic imaging

Upper limb arterial Doppler ultrasound 
How would you rate the appropriateness of the following items for monitoring the clinical course of patients with Raynaud's phenomenon secondary to a connective $\underline{\text { tissue disease other than systemic sclerosis in clinical settings? }}$

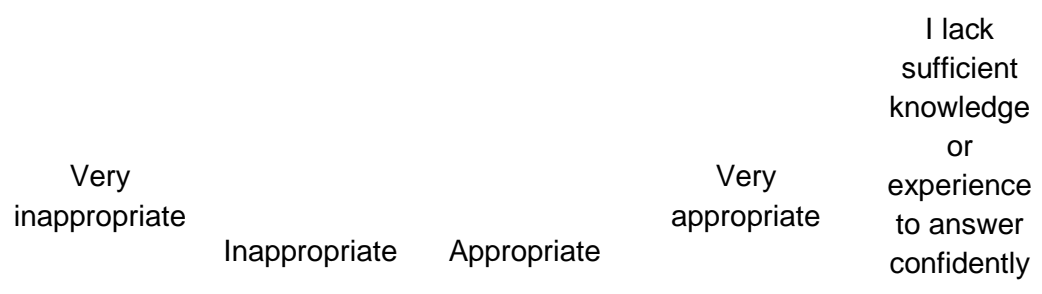

Nailfold videocapillaroscopy

Nailfold dermoscopy

Nailfold stereomicroscopy

Nailfold USB digital microscopy

Laser Doppler flowmetry

Laser Doppler imaging

Laser Doppler anemometry/velocimetry

Laser Speckle Contrast Analysis (LASCA)

Thermographic imaging

Upper limb arterial Doppler ultrasound

How would you rate the appropriateness of the following items for monitoring the clinical course of patients with Raynaud's phenomenon secondary to systemic sclerosis in clinical settings?

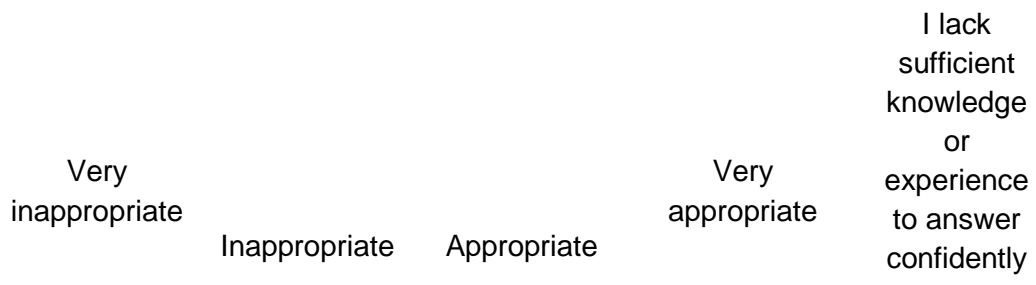

Nailfold videocapillaroscopy

Nailfold dermoscopy

Nailfold stereomicroscopy

Nailfold USB digital microscopy

Laser Doppler flowmetry

Laser Doppler imaging 
Laser Speckle Contrast Analysis (LASCA)

Thermographic imaging

Upper limb arterial Doppler ultrasound

\section{Research Setting}

The following questions are designed to evaluate the appropriateness of different techniques to assess the microcirculation in Raynaud's phenomenon in a research setting (i.e. outcome measure in clinical trials).

How would you rate the appropriateness of the following items for the global assessment of microcirculation in primary and secondary Raynaud's phenomenon in a research setting?

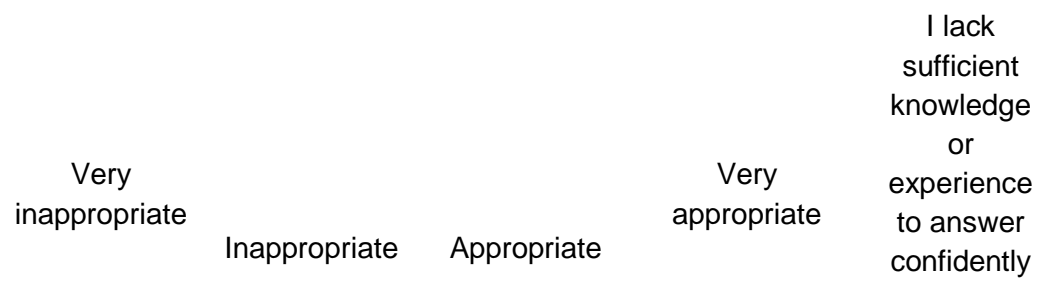

Nailfold videocapillaroscopy

Nailfold dermoscopy

Nailfold stereomicroscopy

Nailfold USB digital microscopy

Laser Doppler flowmetry

Laser Doppler imaging

Laser Doppler anemometry/velocimetry

Laser Speckle Contrast Analysis (LASCA)

Thermographic imaging

Upper limb arterial Doppler ultrasound 
How would you rate the appropriateness of the following items for the differential diagnosis of primary and secondary Raynaud's phenomenon in a research setting?

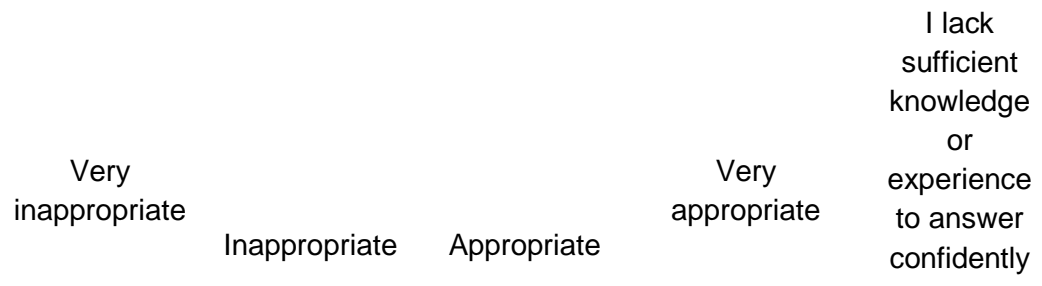

Nailfold videocapillaroscopy

Nailfold dermoscopy

Nailfold stereomicroscopy

Nailfold USB digital microscopy

Laser Doppler flowmetry

Laser Doppler imaging

Laser Doppler anemometry/velocimetry

Laser Speckle Contrast Analysis (LASCA)

Thermographic imaging

Upper limb arterial Doppler ultrasound

How would you rate the appropriateness of the following items as an outcome measure in patients with primary Raynaud's phenomenon in research settings?

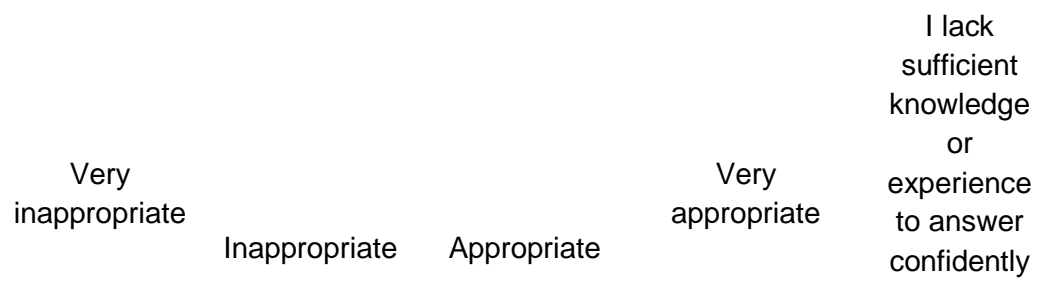

Nailfold videocapillaroscopy

Nailfold dermoscopy

Nailfold stereomicroscopy

Nailfold USB digital microscopy

Laser Doppler flowmetry

Laser Doppler imaging 
Laser Doppler anemometry/velocimetry

Laser Speckle Contrast Analysis (LASCA)

Thermographic imaging

Upper limb arterial Doppler ultrasound

How would you rate the appropriateness of the following items as an outcome measure in patients with Raynaud's phenomenon secondary to a connective tissue disease other than systemic sclerosis in research settings?

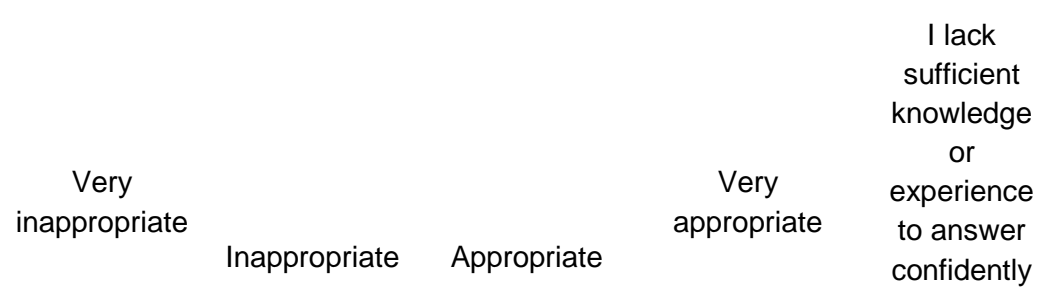

Nailfold videocapillaroscopy

Nailfold dermoscopy

$\square$

$\square$

$\square$

Nailfold stereomicroscopy

Nailfold USB digital microscopy

Laser Doppler flowmetry

Laser Doppler imaging

Laser Doppler anemometry/velocimetry

Laser Speckle Contrast Analysis (LASCA)

Thermographic imaging

Upper limb arterial Doppler ultrasound

How would you rate the appropriateness of the following items as an outcome measure in patients with Raynaud's phenomenon secondary to systemic sclerosis in research settings?

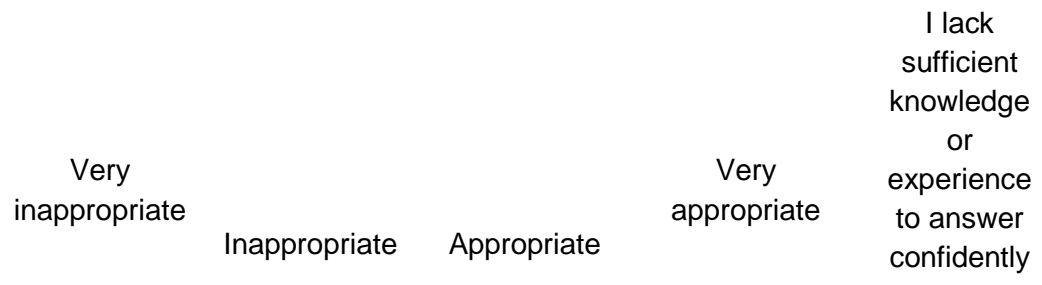


Nailfold USB digital microscopy

Laser Doppler flowmetry

Laser Doppler flowmetry

Laser Doppler imaging

Laser Doppler anemometry/velocimetry

Laser Speckle Contrast Analysis (LASCA)

\section{Thermographic imaging}

Upper limb arterial Doppler ultrasound 
eTable 1. Summary of how often rheumatologists taking care of adults monitor their patients with primary and secondary Raynaud's phenomenon in relation to the number of patients under their care per year.

\begin{tabular}{|c|c|c|c|c|c|}
\hline \multicolumn{6}{|l|}{ primary Rp } \\
\hline \multirow[b]{2}{*}{ Frequency of monitoring } & \multicolumn{5}{|c|}{ No. patients/year } \\
\hline & None & $<30$ & $31-60$ & $61-100$ & $>100$ \\
\hline Never & $2(100 \%)$ & $0(0 \%)$ & $1(3.9 \%)$ & $1(7.1 \%)$ & $0(0 \%)$ \\
\hline $\begin{array}{l}\text { Only if required on the basis of } \\
\text { clinical progression }\end{array}$ & $0(0 \%)$ & $18(58.0 \%)$ & $12(46.1 \%)$ & $3(21.4 \%)$ & $4(26.7 \%)$ \\
\hline $\begin{array}{l}\text { Once, independently of clinical } \\
\text { progression }\end{array}$ & $0(0 \%)$ & $3(9.7 \%)$ & $2(7.7 \%)$ & $1(7.1 \%)$ & $0(0 \%)$ \\
\hline $\begin{array}{l}\text { Periodically, independently of } \\
\text { clinical progression (less than once } \\
\text { a year) }\end{array}$ & $0(0 \%)$ & $4(12.9 \%)$ & $6(23.1 \%)$ & $4(28.6 \%)$ & $6(40.0 \%)$ \\
\hline $\begin{array}{l}\text { Periodically, independently of } \\
\text { clinical progression (twice a year) }\end{array}$ & $0(0 \%)$ & $3(9.7 \%)$ & $5(19.2 \%)$ & $5(35.8 \%)$ & $3(20.0 \%)$ \\
\hline $\begin{array}{l}\text { Periodically, independently of } \\
\text { clinical progression (more than twice } \\
\text { a year) }\end{array}$ & $0(0 \%)$ & $3(9.7 \%)$ & $0(0 \%)$ & $0(0 \%)$ & $2(13.3 \%)$ \\
\hline \multicolumn{6}{|l|}{ Rp secondary to CTDs } \\
\hline Never & $0(0 \%)$ & $1(4.2 \%)$ & $2(7.1 \%)$ & $0(0 \%)$ & $2(8.7 \%)$ \\
\hline $\begin{array}{l}\text { Only if required on the basis of } \\
\text { clinical progression }\end{array}$ & $0(0 \%)$ & $9(37.5 \%)$ & $10(35.7 \%)$ & $7(53.8 \%)$ & $5(21.7 \%)$ \\
\hline $\begin{array}{l}\text { Once, independently of clinical } \\
\text { progression }\end{array}$ & $0(0 \%)$ & $1(4.2 \%)$ & $2(7.1 \%)$ & $1(7.7 \%)$ & $1(4.4 \%)$ \\
\hline $\begin{array}{l}\text { Periodically, independently of } \\
\text { clinical progression (less than once } \\
\text { a year) }\end{array}$ & $0(0 \%)$ & $5(20.8 \%)$ & 5 (17.9\%) & $3(23.1 \%)$ & $8(34.8 \%)$ \\
\hline $\begin{array}{l}\text { Periodically, independently of } \\
\text { clinical progression (twice a year) }\end{array}$ & $0(0 \%)$ & $5(20.8 \%)$ & $7(25.1 \%)$ & $1(7.7 \%)$ & $2(8.7 \%)$ \\
\hline
\end{tabular}




\begin{tabular}{|c|c|c|c|c|c|}
\hline $\begin{array}{l}\text { Periodically, independently of } \\
\text { clinical progression (more than twice } \\
\text { a year) }\end{array}$ & $0(0 \%)$ & $3(12.5 \%)$ & $2(7.1 \%)$ & $1(7.7 \%)$ & $5(21.7 \%)$ \\
\hline \multicolumn{6}{|l|}{ Rp secondary to SSc } \\
\hline Never & $0(0 \%)$ & $0(0 \%)$ & $0(0 \%)$ & $0(0 \%)$ & $1(3.3 \%)$ \\
\hline $\begin{array}{l}\text { Only if required on the basis of } \\
\text { clinical progression }\end{array}$ & $0(0 \%)$ & $2(12.5 \%)$ & $5(18.5 \%)$ & $3(20.0 \%)$ & $9(30.0 \%)$ \\
\hline $\begin{array}{l}\text { Once, independently of clinical } \\
\text { progression }\end{array}$ & $0(0 \%)$ & $1(6.3 \%)$ & $2(7.4 \%)$ & $2(13.3 \%)$ & $3(10.0 \%)$ \\
\hline $\begin{array}{l}\text { Periodically, independently of } \\
\text { clinical progression (less than once } \\
\text { a year) }\end{array}$ & $0(0 \%)$ & $3(18.7 \%)$ & $8(29.7 \%)$ & $5(33.3 \%)$ & $11(36.7 \%)$ \\
\hline $\begin{array}{l}\text { Periodically, independently of } \\
\text { clinical progression (twice a year) }\end{array}$ & $0(0 \%)$ & $6(37.5 \%)$ & $9(33.3 \%)$ & $4(26.7 \%)$ & $1(3.3 \%)$ \\
\hline $\begin{array}{l}\text { Periodically, independently of } \\
\text { clinical progression (more than twice } \\
\text { a year) }\end{array}$ & $0(0 \%)$ & $4(25.0 \%)$ & $3(11.1 \%)$ & $1(6.7 \%)$ & $5(16.7 \%)$ \\
\hline
\end{tabular}

RP: Raynaud's phenomenon, CTD: connective tissue disease; SSc: systemic sclerosis 
eTable 2. Results from rheumatologists take care of adults on the role of imaging techniques other than capillaroscopy in the management of Rp in clinical practice $(A)$ and research setting (B).

A.

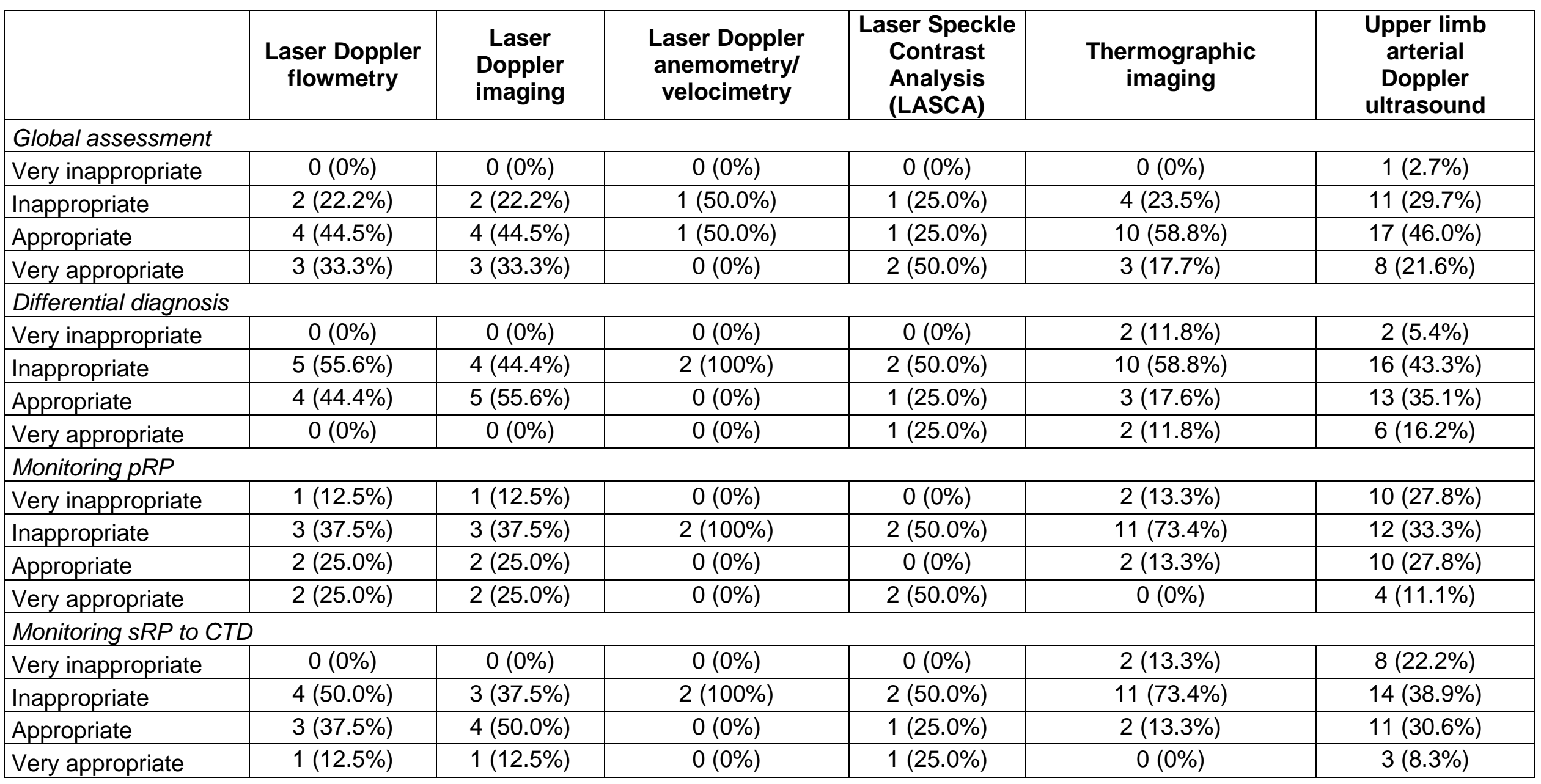




\begin{tabular}{|c|c|c|c|c|c|c|}
\hline \multicolumn{7}{|c|}{ Monitoring SRP to SSc } \\
\hline Very inappropriate & $0(0 \%)$ & $0(0 \%)$ & $0(0 \%)$ & $0(0 \%)$ & $1(5.9 \%)$ & $5(13.5 \%)$ \\
\hline Inappropriate & $3(33.3 \%)$ & $3(37.5 \%)$ & $2(100 \%)$ & $2(50.0 \%)$ & $10(58.8 \%)$ & $15(40.6 \%)$ \\
\hline Appropriate & $4(44.5 \%)$ & $3(37.5 \%)$ & $0(0 \%)$ & $0(0 \%)$ & $6(35.3 \%)$ & $12(32.4 \%)$ \\
\hline Very appropriate & $2(22.2 \%)$ & $2(25.0 \%)$ & $0(0 \%)$ & $2(50.0 \%)$ & $0(0 \%)$ & $5(13.5 \%)$ \\
\hline
\end{tabular}

B.

\begin{tabular}{|c|c|c|c|c|c|c|}
\hline & $\begin{array}{l}\text { Laser Doppler } \\
\text { flowmetry }\end{array}$ & $\begin{array}{l}\text { Laser } \\
\text { Doppler } \\
\text { imaging }\end{array}$ & $\begin{array}{l}\text { Laser Doppler } \\
\text { anemometryl } \\
\text { velocimetry }\end{array}$ & $\begin{array}{c}\text { Laser Speckle } \\
\text { Contrast } \\
\text { Analysis } \\
\text { (LASCA) }\end{array}$ & $\begin{array}{c}\text { Thermographic } \\
\text { imaging }\end{array}$ & $\begin{array}{l}\text { Upper limb } \\
\text { arterial } \\
\text { Doppler } \\
\text { ultrasound }\end{array}$ \\
\hline \multicolumn{7}{|l|}{ Global assessment } \\
\hline Very inappropriate & $0(0 \%)$ & $0(0 \%)$ & $0(0 \%)$ & $0(0 \%)$ & $1(5.9 \%)$ & $4(10.8 \%)$ \\
\hline Inappropriate & $0(0 \%)$ & $0(0 \%)$ & $0(0 \%)$ & $0(0 \%)$ & $8(47.0 \%)$ & $10(27.0 \%)$ \\
\hline Appropriate & $5(55.6 \%)$ & $2(22.2 \%)$ & $0(0 \%)$ & $0(0 \%)$ & $7(41.2 \%)$ & $15(40.6 \%)$ \\
\hline Very appropriate & $4(44.4 \%)$ & $7(77.8 \%)$ & $2(100 \%)$ & $4(100 \%)$ & $1(5.9 \%)$ & $8(21.6 \%)$ \\
\hline \multicolumn{7}{|l|}{ Differential diagnosis } \\
\hline Very inappropriate & $0(0 \%)$ & $0(0 \%)$ & $0(0 \%)$ & $0(0 \%)$ & $1(6.7 \%)$ & $4(11.1 \%)$ \\
\hline Inappropriate & $0(0 \%)$ & $1(11.1 \%)$ & $0(0 \%)$ & $0(0 \%)$ & $6(40.0 \%)$ & $13(36.1 \%)$ \\
\hline Appropriate & $6(75.0 \%)$ & $3(33.3 \%)$ & $0(0 \%)$ & $0(0 \%)$ & $7(46.6 \%)$ & $11(30.6 \%)$ \\
\hline Very appropriate & $2(25.0 \%)$ & $5(55.6 \%)$ & $1(100 \%)$ & $4(100 \%)$ & $1(6.7 \%)$ & $8(22.2 \%)$ \\
\hline \multicolumn{7}{|c|}{ Outcome measure for $p R P$} \\
\hline Very inappropriate & $0(0 \%)$ & $0(0 \%)$ & $0(0 \%)$ & $0(0 \%)$ & $1(6.3 \%)$ & $8(22.2 \%)$ \\
\hline Inappropriate & $0(0 \%)$ & $1(11.1 \%)$ & $1(50.0 \%)$ & $0(0 \%)$ & $5(31.2 \%)$ & $13(36.1 \%)$ \\
\hline Appropriate & $5(62.5 \%)$ & $5(55.6 \%)$ & $0(0 \%)$ & $1(25.0 \%)$ & $9(56.2 \%)$ & $12(33.4 \%)$ \\
\hline Very appropriate & $3(37.5 \%)$ & $3(33.3 \%)$ & $1(50.0 \%)$ & $3(75.0 \%)$ & $1(6.3 \%)$ & $3(8.3 \%)$ \\
\hline \multicolumn{7}{|c|}{ Outcome measure for sRP to CTD } \\
\hline Very inappropriate & $0(0 \%)$ & $0(0 \%)$ & $0(0 \%)$ & $0(0 \%)$ & $1(5.9 \%)$ & $5(13.2 \%)$ \\
\hline Inappropriate & $0(0 \%)$ & $1(11.0 \%)$ & $0(0 \%)$ & $0(0 \%)$ & $8(47.0 \%)$ & $12(31.5 \%)$ \\
\hline Appropriate & $5(55.6 \%)$ & $4(44.5 \%)$ & $0(0 \%)$ & $1(25.0 \%)$ & $7(41.2 \%)$ & $16(42.1 \%)$ \\
\hline
\end{tabular}




\begin{tabular}{|l|c|c|c|c|c|c|}
\hline Very appropriate & $4(44.4 \%)$ & $4(44.5 \%)$ & $1(100 \%)$ & $3(75.0 \%)$ & $1(5.9 \%)$ & $5(13.2 \%)$ \\
\hline Outcome measure for sRP to SSc & \multicolumn{5}{|c|}{} \\
\hline Very inappropriate & $0(0 \%)$ & $0(0 \%)$ & $0(0 \%)$ & $0(0 \%)$ & $1(6.3 \%)$ & $5(13.2 \%)$ \\
\hline Inappropriate & $0(0 \%)$ & $0(0 \%)$ & $1(50.0 \%)$ & $0(0 \%)$ & $7(43.7 \%)$ & $10(26.3 \%)$ \\
\hline Appropriate & $5(62.5 \%)$ & $4(50.0 \%)$ & $0(0 \%)$ & $1(25.0 \%)$ & $6(37.5 \%)$ & $16(42.1 \%)$ \\
\hline Very appropriate & $3(37.5 \%)$ & $4(50.0 \%)$ & $1(50.0 \%)$ & $3(75.0 \%)$ & $2(12.5 \%)$ & $7(18.4 \%)$ \\
\hline
\end{tabular}


eTable 3. Summary of how often paediatric rheumatologists monitor their patients with primary and secondary Raynaud's phenomenon in relation to the number of patients under their care per year.

\begin{tabular}{|c|c|c|c|c|c|}
\hline \multicolumn{6}{|l|}{ primary Rp } \\
\hline \multirow[b]{2}{*}{ Frequency of monitoring } & \multicolumn{5}{|c|}{ No. patients/year } \\
\hline & None & $<30$ & $31-60$ & $61-100$ & $>100$ \\
\hline Never & $0(0 \%)$ & $0(0.0 \%)$ & $0(0.0 \%)$ & $0(0 \%)$ & $0(0 \%)$ \\
\hline $\begin{array}{l}\text { Only if required on the basis of } \\
\text { clinical progression }\end{array}$ & $0(0 \%)$ & $5(38.5 \%)$ & $1(25.0 \%)$ & $0(0 \%)$ & $0(0 \%)$ \\
\hline $\begin{array}{l}\text { Once, independently of clinical } \\
\text { progression }\end{array}$ & $0(0 \%)$ & $1(7.7 \%)$ & $2(50.0 \%)$ & $0(0 \%)$ & $0(0 \%)$ \\
\hline $\begin{array}{l}\text { Periodically, independently of } \\
\text { clinical progression (less than once } \\
\text { a year) }\end{array}$ & $0(0 \%)$ & $1(7.7 \%)$ & $1(25.0 \%)$ & $0(0 \%)$ & $0(0 \%)$ \\
\hline $\begin{array}{l}\text { Periodically, independently of } \\
\text { clinical progression (twice a year) }\end{array}$ & $0(0 \%)$ & $4(30.7 \%)$ & $0(0 \%)$ & $0(0 \%)$ & $0(0 \%)$ \\
\hline $\begin{array}{l}\text { Periodically, independently of } \\
\text { clinical progression (more than twice } \\
\text { a year) }\end{array}$ & $0(0 \%)$ & $2(15.4 \%)$ & $0(0 \%)$ & $0(0 \%)$ & $1(100.0 \%)$ \\
\hline \multicolumn{6}{|l|}{ Rp secondary to CTDs } \\
\hline Never & $0(0 \%)$ & $0(0 \%)$ & $0(0 \%)$ & $0(0 \%)$ & $0(0 \%)$ \\
\hline $\begin{array}{l}\text { Only if required on the basis of } \\
\text { clinical progression }\end{array}$ & $0(0 \%)$ & $4(25.0 \%)$ & $0(0 \%)$ & $0(0 \%)$ & $0(0 \%)$ \\
\hline $\begin{array}{l}\text { Once, independently of clinical } \\
\text { progression }\end{array}$ & $0(0 \%)$ & $1(6.2 \%)$ & $0(0 \%)$ & $0(0 \%)$ & $0(0 \%)$ \\
\hline $\begin{array}{l}\text { Periodically, independently of } \\
\text { clinical progression (less than once } \\
\text { a year) }\end{array}$ & $0(0 \%)$ & $3(18.8 \%)$ & $0(0 \%)$ & $0(0 \%)$ & $0(0 \%)$ \\
\hline
\end{tabular}




\begin{tabular}{|l|c|c|c|c|c|}
\hline $\begin{array}{l}\text { Periodically, independently of } \\
\text { clinical progression (twice a year) }\end{array}$ & $0(0 \%)$ & $3(18.8 \%)$ & $0(0.0 \%)$ & $0(0 \%)$ & $0(0 \%)$ \\
\hline $\begin{array}{l}\text { Periodically, independently of } \\
\text { clinical progression (more than twice } \\
\text { a year) }\end{array}$ & $0(0 \%)$ & $5(31.2 \%)$ & $2(100.0 \%)$ & $0(0 \%)$ \\
\hline Rp secondary to SSc & $0(0 \%)$ & $0(0 \%)$ & $0(0 \%)$ & $0(0 \%)$ & $0(0 \%)$ \\
\hline Never & $0(0 \%)$ & $3(16.7 \%)$ & $0(0 \%)$ & $0(0 \%)$ \\
\hline $\begin{array}{l}\text { Only if required on the basis of } \\
\text { clinical progression }\end{array}$ & $0(0 \%)$ & $1(5.5 \%)$ & $0(0 \%)$ & $0(0 \%)$ & $0(0 \%)$ \\
\hline $\begin{array}{l}\text { Once, independently of clinical } \\
\text { progression }\end{array}$ & $0(0 \%)$ & $3(16.7 \%)$ & $0(0 \%)$ & $0(0 \%)$ \\
\hline $\begin{array}{l}\text { Periodically, independently of } \\
\text { clinical progression (less than once } \\
\text { a year) }\end{array}$ & $0(0 \%)$ & $3(16.7 \%)$ & $0(0 \%)$ & $0(0 \%)$ & $0(0 \%)$ \\
\hline $\begin{array}{l}\text { Periodically, independently of } \\
\text { clinical progression (twice a year) }\end{array}$ & $0(0 \%)$ & $8(44.4 \%)$ & $0(0 \%)$ & $0(0 \%)$ & $0(0 \%)$ \\
\hline $\begin{array}{l}\text { Periodically, independently of } \\
\text { clinical progression (more than twice } \\
\text { a year) }\end{array}$ & & & $0 \%$ \\
\hline
\end{tabular}

RP: Raynaud's phenomenon, CTD: connective tissue disease; SSc: systemic sclerosis 
eTable 4. Overall view on the real-world usage and availability of imaging techniques by paediatric rheumatologists.

\begin{tabular}{|c|c|c|c|c|c|c|c|c|c|c|}
\hline \multicolumn{11}{|c|}{ Frequency of use } \\
\hline Seldom & $3(16.7 \%)$ & $4(22.2 \%)$ & $3(16.7 \%)$ & $2(11.1 \%)$ & $1(5.6 \%)$ & $0(0 \%)$ & $0(0 \%)$ & $0(0 \%)$ & $1(5.6 \%)$ & $4(22.2 \%)$ \\
\hline Sometimes & $4(22.2 \%)$ & $1(5.6 \%)$ & $1(5.6 \%)$ & $0(0 \%)$ & $0(0 \%)$ & $1(5.6 \%)$ & $0(0 \%)$ & $0(0 \%)$ & $0(0 \%)$ & $5(27.8 \%)$ \\
\hline Not available & $8(44.4 \%)$ & $2(11.1 \%)$ & $14(77.7 \%)$ & $18(100 \%)$ & $15(83.3 \%)$ & $15(83.3 \%)$ & $16(88.8 \%)$ & $18(100 \%)$ & $15(83.3 \%)$ & $2(11.1 \%)$ \\
\hline $\begin{array}{l}\text { Available in } \\
\text { my place of } \\
\text { work }\end{array}$ & $7(38.9 \%)$ & $12(66.7 \%)$ & $2(11.1 \%)$ & $0(0 \%)$ & $1(5.6 \%)$ & $1(5.6 \%)$ & $0(0 \%)$ & $0(0 \%)$ & $0(0 \%)$ & $7(38.9 \%)$ \\
\hline $\begin{array}{l}\text { Avalilable in } \\
\text { another } \\
\text { hospital }\end{array}$ & $3(16.7 \%)$ & $1(5.5 \%)$ & $1(5.6 \%)$ & $0(0 \%)$ & $2(11.1 \%)$ & $2(11.1 \%)$ & $1(5.6 \%)$ & $0(0 \%)$ & $2(11.1 \%)$ & $2(11.1 \%)$ \\
\hline \multicolumn{11}{|c|}{ Who perform the exam } \\
\hline I do it & $4(22.2 \%)$ & $12(66.6 \%)$ & $2(11.1 \%)$ & $0(0 \%)$ & $0(0 \%)$ & $0(0 \%)$ & $0(0 \%)$ & $0(0 \%)$ & $0(0 \%)$ & $0(0 \%)$ \\
\hline Technicians & $1(5.6 \%)$ & $1(5.6 \%)$ & $1(5.6 \%)$ & $0(0 \%)$ & $0(0 \%)$ & $0(0 \%)$ & $0(0 \%)$ & $0(0 \%)$ & $2(11.1 \%)$ & $5(27.8 \%)$ \\
\hline Nurses & $0(0 \%)$ & $0(0 \%)$ & $0(0 \%)$ & $0(0 \%)$ & $0(0 \%)$ & $0(0 \%)$ & $0(0 \%)$ & $0(0 \%)$ & $0(0 \%)$ & $0(0 \%)$ \\
\hline Other spec & $5(27.8 \%)$ & $3(16.7 \%)$ & 2 (11.1\%) & $0(0 \%)$ & $3(16.7 \%)$ & $3(16.7 \%)$ & $1(5.6 \%)$ & $0(0 \%)$ & $0(0 \%)$ & $9(50.0 \%)$ \\
\hline $\begin{array}{l}\text { Not } \\
\text { applicable }\end{array}$ & $8(44.4 \%)$ & $2(11.1 \%)$ & $13(72.2 \%)$ & 18 (100\%) & 15 (83.3\%) & 15 (83.3\%) & $17(94.4 \%)$ & $18(100 \%)$ & $16(88.9 \%)$ & $4(22.2 \%)$ \\
\hline
\end{tabular}

LASCA: Laser Speckle Contrast Analysis 
eTable 5. Results from paediatric rheumatologists on the role of capillaroscopic techniques in the management of Rp in clinical practice $(A)$ and research setting $(B)$.

A.

\begin{tabular}{|c|c|c|c|c|}
\hline & $\begin{array}{c}\text { Nailfold } \\
\text { video } \\
\text { capillaroscopy }\end{array}$ & $\begin{array}{c}\text { Nailfold } \\
\text { dermoscopy }\end{array}$ & $\begin{array}{l}\text { Nailfold stereo } \\
\text { microscopy }\end{array}$ & $\begin{array}{c}\text { Nailfold digital } \\
\text { USB } \\
\text { Microscopy }\end{array}$ \\
\hline \multicolumn{5}{|l|}{ Global assessment } \\
\hline Very inappropriate & $0(0 \%)$ & $0(0 \%)$ & $0(0 \%)$ & $0(0 \%)$ \\
\hline Inappropriate & $0(0 \%)$ & $0(0 \%)$ & $0(0 \%)$ & $1(20.0 \%)$ \\
\hline Appropriate & $4(30.8 \%)$ & $3(27.3 \%)$ & $4(57.1 \%)$ & $4(80.0 \%)$ \\
\hline Very appropriate & $9(69.2 \%)$ & $8(72.7 \%)$ & $3(42.9 \%)$ & $0(0 \%)$ \\
\hline \multicolumn{5}{|l|}{ Differential diagnosis } \\
\hline Very inappropriate & $0(0 \%)$ & $0(0 \%)$ & $0(0 \%)$ & $0(0 \%)$ \\
\hline Inappropriate & $2(15.4 \%)$ & $2(18.2 \%)$ & $1(14.3 \%)$ & $0(0 \%)$ \\
\hline Appropriate & $5(38.5 \%)$ & $3(27.3 \%)$ & $2(28.6 \%)$ & $2(50.0 \%)$ \\
\hline Very appropriate & $6(46.2 \%)$ & $6(54.5 \%)$ & $4(57.1 \%)$ & $2(50.0 \%)$ \\
\hline \multicolumn{5}{|l|}{ Monitoring $p R P$} \\
\hline Very inappropriate & $0(0 \%)$ & $0(0 \%)$ & $0(0 \%)$ & $0(0 \%)$ \\
\hline Inappropriate & $1(7.7 \%)$ & $2(18.2 \%)$ & $0(0 \%)$ & $1(25.0 \%)$ \\
\hline Appropriate & $3(23.1 \%)$ & $6(54.5 \%)$ & $3(42.9 \%)$ & $2(50.0 \%)$ \\
\hline Very appropriate & $9(69.2 \%)$ & $3(27.3 \%)$ & $4(57.1 \%)$ & $1(25.0 \%)$ \\
\hline \multicolumn{5}{|c|}{ Monitoring SRP to CTD } \\
\hline Very inappropriate & $0(0 \%)$ & $0(0 \%)$ & $0(0 \%)$ & $0(0 \%)$ \\
\hline Inappropriate & $1(7.6 \%)$ & $2(18.2 \%)$ & $0(0 \%)$ & $1(25.0 \%)$ \\
\hline Appropriate & $6(46.2 \%)$ & $5(45.4 \%)$ & $4(57.1 \%)$ & $3(75.0 \%)$ \\
\hline Very appropriate & $6(46.2 \%)$ & $4(36.4 \%)$ & $3(42.9 \%)$ & $0(0 \%)$ \\
\hline \multicolumn{5}{|c|}{ Monitoring SRP to SSc } \\
\hline Very inappropriate & $0(0 \%)$ & $0(0 \%)$ & $0(0 \%)$ & $0(0 \%)$ \\
\hline Inappropriate & $1(7.7 \%)$ & $2(16.6 \%)$ & $0(0 \%)$ & $1(20.0 \%)$ \\
\hline Appropriate & $5(38.5 \%)$ & $5(41.7 \%)$ & $3(42.9 \%)$ & $3(60.0 \%)$ \\
\hline Very appropriate & $7(53.8 \%)$ & $5(41.7 \%)$ & $4(57.1 \%)$ & $1(20.0 \%)$ \\
\hline
\end{tabular}


B.

\begin{tabular}{|c|c|c|c|c|}
\hline & $\begin{array}{c}\text { Nailfold } \\
\text { video } \\
\text { capillaroscopy }\end{array}$ & $\begin{array}{c}\text { Nailfold } \\
\text { dermoscopy }\end{array}$ & $\begin{array}{l}\text { Nailfold stereo } \\
\text { microscopy }\end{array}$ & $\begin{array}{l}\text { Nailfold digital } \\
\text { USB } \\
\text { Microscopy }\end{array}$ \\
\hline \multicolumn{5}{|l|}{ Global assessment } \\
\hline Very inappropriate & $0(0 \%)$ & $0(0 \%)$ & $0(0 \%)$ & $0(0 \%)$ \\
\hline Inappropriate & $0(0 \%)$ & $2(18.2 \%)$ & $0(0 \%)$ & $0(0 \%)$ \\
\hline Appropriate & $2(15.4 \%)$ & $7(63.6 \%)$ & $3(42.9 \%)$ & $3(75.0 \%)$ \\
\hline Very appropriate & $11(84.6 \%)$ & $2(18.2 \%)$ & $4(57.1 \%)$ & $1(25.0 \%)$ \\
\hline \multicolumn{5}{|l|}{ Differential diagnosis } \\
\hline Very inappropriate & $0(0 \%)$ & $0(0 \%)$ & $0(0 \%)$ & $0(0 \%)$ \\
\hline Inappropriate & $0(0 \%)$ & $3(27.3 \%)$ & $0(0 \%)$ & $0(0 \%)$ \\
\hline Appropriate & $2(15.4 \%)$ & $6(54.5 \%)$ & $3(42.9 \%)$ & $2(66.7 \%)$ \\
\hline Very appropriate & $11(84.6 \%)$ & $2(18.2 \%)$ & $4(57.1 \%)$ & $1(33.3 \%)$ \\
\hline \multicolumn{5}{|c|}{ Outcome measure in $p R P$} \\
\hline Very inappropriate & $0(0 \%)$ & $0(0 \%)$ & $0(0 \%)$ & $0(0 \%)$ \\
\hline Inappropriate & $2(15.4 \%)$ & $3(27.3 \%)$ & $0(0 \%)$ & $0(0 \%)$ \\
\hline Appropriate & $4(30.8 \%)$ & $7(63.6 \%)$ & $4(57.1 \%)$ & $3(100 \%)$ \\
\hline Very appropriate & $7(53.8 \%)$ & $1(9.1 \%)$ & $3(42.9 \%)$ & $0(0 \%)$ \\
\hline \multicolumn{5}{|c|}{ Outcome measure in SRP to CTD } \\
\hline Very inappropriate & $0(0 \%)$ & $0(0 \%)$ & $0(0 \%)$ & $0(0 \%)$ \\
\hline Inappropriate & $0(0 \%)$ & $3(27.3 \%)$ & $0(0 \%)$ & $0(0 \%)$ \\
\hline Appropriate & $4(30.8 \%)$ & $7(63.6 \%)$ & $5(71.4 \%)$ & $3(100 \%)$ \\
\hline Very appropriate & $9(69.2 \%)$ & $1(9.1 \%)$ & $2(28.6 \%)$ & $0(0 \%)$ \\
\hline \multicolumn{5}{|c|}{ Outcome measure in SRP to SSc } \\
\hline Very inappropriate & $0(0 \%)$ & $0(0 \%)$ & $0(0 \%)$ & $0(0 \%)$ \\
\hline Inappropriate & $0(0 \%)$ & $3(27.3 \%)$ & $0(0 \%)$ & $0(0 \%)$ \\
\hline Appropriate & $3(23.1 \%)$ & $7(63.6 \%)$ & $5(71.4 \%)$ & $3(100 \%)$ \\
\hline Very appropriate & $10(76.9 \%)$ & $1(9.1 \%)$ & $2(28.6 \%)$ & $0(0 \%)$ \\
\hline
\end{tabular}


eTable 6. Results from paediatric rheumatologists on the role of imaging techniques other than capillaroscopy in the management of $R p$ in clinical practice $(A)$ and research setting (B).

A.

\begin{tabular}{|c|c|c|c|c|c|c|}
\hline & $\begin{array}{l}\text { Laser } \\
\text { Doppler } \\
\text { flowmetry }\end{array}$ & $\begin{array}{l}\text { Laser } \\
\text { Doppler } \\
\text { imaging }\end{array}$ & $\begin{array}{c}\text { Laser } \\
\text { Doppler } \\
\text { anemometryl } \\
\text { velocimetry }\end{array}$ & $\begin{array}{c}\text { Laser } \\
\text { Speckle } \\
\text { Contrast } \\
\text { Analysis } \\
\text { (LASCA) }\end{array}$ & $\begin{array}{c}\text { Thermographic } \\
\text { imaging }\end{array}$ & $\begin{array}{l}\text { Upper } \operatorname{limb} \\
\text { arterial } \\
\text { Doppler } \\
\text { ultrasound }\end{array}$ \\
\hline \multicolumn{7}{|c|}{ Global assessment } \\
\hline $\begin{array}{l}\text { Very } \\
\text { inappropriate }\end{array}$ & $0(0 \%)$ & $0(0 \%)$ & $0(0 \%)$ & $0(0 \%)$ & $0(0 \%)$ & $0(0 \%)$ \\
\hline Inappropriate & $2(50.0 \%)$ & $3(60.0 \%)$ & $0(0 \%)$ & $0(0 \%)$ & $1(50.0 \%)$ & $1(25.0 \%)$ \\
\hline Appropriate & $2(50.0 \%)$ & $2(40.0 \%)$ & $1(100 \%)$ & $1(100 \%)$ & $1(50.0 \%)$ & $3(75.0 \%)$ \\
\hline $\begin{array}{l}\text { Very } \\
\text { appropriate }\end{array}$ & $0(0 \%)$ & $0(0 \%)$ & $0(0 \%)$ & $0(0 \%)$ & $0(0 \%)$ & $0(0 \%)$ \\
\hline \multicolumn{7}{|c|}{ Differential diagnosis } \\
\hline $\begin{array}{l}\text { Very } \\
\text { inappropriate }\end{array}$ & $0(0 \%)$ & $0(0 \%)$ & $0(0 \%)$ & $0(0 \%)$ & $0(0 \%)$ & $0(0 \%)$ \\
\hline Inappropriate & $2(50.0 \%)$ & $3(60.0 \%)$ & $0(0 \%)$ & $0(0 \%)$ & $1(50.0 \%)$ & $3(60.0 \%)$ \\
\hline Appropriate & $0(0 \%)$ & $0(0 \%)$ & $0(0 \%)$ & $0(0 \%)$ & $0(0 \%)$ & $2(40.0 \%)$ \\
\hline $\begin{array}{l}\text { Very } \\
\text { appropriate }\end{array}$ & $2(50.0 \%)$ & $2(40.0 \%)$ & $1(100 \%)$ & $1(100 \%)$ & $1(50.0 \%)$ & $0(0 \%)$ \\
\hline \multicolumn{7}{|c|}{ Monitoring $p R P$} \\
\hline $\begin{array}{l}\text { Very } \\
\text { inappropriate }\end{array}$ & $0(0 \%)$ & $0(0 \%)$ & $0(0 \%)$ & $0(0 \%)$ & $0(0 \%)$ & $0(0 \%)$ \\
\hline Inappropriate & $1(25.0 \%)$ & $2(40.0 \%)$ & $0(0 \%)$ & $0(0 \%)$ & $0(0 \%)$ & $2(40.0 \%)$ \\
\hline Appropriate & $2(50.0 \%)$ & $2(40.0 \%)$ & $1(100 \%)$ & $1(100 \%)$ & $1(50.0 \%)$ & $3(60.0 \%)$ \\
\hline $\begin{array}{l}\text { Very } \\
\text { appropriate }\end{array}$ & $1(25.0 \%)$ & $1(20.0 \%)$ & $0(0 \%)$ & $0(0 \%)$ & $1(50.0 \%)$ & $0(0 \%)$ \\
\hline \multicolumn{7}{|c|}{ Monitoring SRP to CTD } \\
\hline $\begin{array}{l}\text { Very } \\
\text { inappropriate }\end{array}$ & $0(0 \%)$ & $0(0 \%)$ & $0(0 \%)$ & $0(0 \%)$ & $0(0 \%)$ & $0(0 \%)$ \\
\hline Inappropriate & $0(0 \%)$ & $1(25.0 \%)$ & $0(0 \%)$ & $0(0 \%)$ & $0(0 \%)$ & $2(40.0 \%)$ \\
\hline Appropriate & $2(66.7 \%)$ & $2(50.0 \%)$ & $1(100 \%)$ & $1(100 \%)$ & $1(50.0 \%)$ & $3(60.0 \%)$ \\
\hline $\begin{array}{l}\text { Very } \\
\text { appropriate }\end{array}$ & $1(33.3 \%)$ & $1(25.0 \%)$ & $0(0 \%)$ & $0(0 \%)$ & $1(50.0 \%)$ & $0(0 \%)$ \\
\hline \multicolumn{7}{|c|}{ Monitoring SRP to SSC } \\
\hline $\begin{array}{l}\text { Very } \\
\text { inappropriate }\end{array}$ & $0(0 \%)$ & $0(0 \%)$ & $0(0 \%)$ & $0(0 \%)$ & $0(0 \%)$ & $0(0 \%)$ \\
\hline Inappropriate & $0(0 \%)$ & $1(25.0 \%)$ & $0(0 \%)$ & $0(0 \%)$ & $0(0 \%)$ & $2(40.0 \%)$ \\
\hline Appropriate & $1(33.3 \%)$ & $1(25.0 \%)$ & $1(100 \%)$ & $1(100 \%)$ & $0(0 \%)$ & $3(60.0 \%)$ \\
\hline $\begin{array}{l}\text { Very } \\
\text { appropriate }\end{array}$ & $2(66.7 \%)$ & $2(50.0 \%)$ & $0(0 \%)$ & $0(0 \%)$ & $2(100 \%)$ & $0(0 \%)$ \\
\hline
\end{tabular}


B.

\begin{tabular}{|c|c|c|c|c|c|c|}
\hline & $\begin{array}{c}\text { Laser } \\
\text { Doppler } \\
\text { flowmetry }\end{array}$ & $\begin{array}{l}\text { Laser } \\
\text { Doppler } \\
\text { imaging }\end{array}$ & $\begin{array}{c}\text { Laser } \\
\text { Doppler } \\
\text { anemometryl } \\
\text { velocimetry }\end{array}$ & $\begin{array}{l}\text { Laser } \\
\text { Speckle } \\
\text { Contrast } \\
\text { Analysis } \\
\text { (LASCA) }\end{array}$ & $\begin{array}{c}\text { Thermographic } \\
\text { imaging }\end{array}$ & $\begin{array}{l}\text { Upper limb } \\
\text { arterial } \\
\text { Doppler } \\
\text { ultrasound }\end{array}$ \\
\hline \multicolumn{7}{|c|}{ Global assessment } \\
\hline $\begin{array}{l}\text { Very } \\
\text { inappropriate }\end{array}$ & $0(0 \%)$ & $0(0 \%)$ & $0(0 \%)$ & $0(0 \%)$ & $0(0 \%)$ & $0(0 \%)$ \\
\hline Inappropriate & $0(0 \%)$ & $1(25.0 \%)$ & $0(0 \%)$ & $0(0 \%)$ & $0(0 \%)$ & $2(40.0 \%)$ \\
\hline Appropriate & $2(66.7 \%)$ & $2(50.0 \%)$ & $1(100 \%)$ & $1(100 \%)$ & $1(50.0 \%)$ & $1(20.0 \%)$ \\
\hline $\begin{array}{l}\text { Very } \\
\text { appropriate }\end{array}$ & $1(33.3 \%)$ & $1(25.0 \%)$ & $0(0 \%)$ & $0(0 \%)$ & $1(50.0 \%)$ & $2(40.0 \%)$ \\
\hline \multicolumn{7}{|c|}{ Differential diagnosis } \\
\hline $\begin{array}{l}\text { Very } \\
\text { inappropriate }\end{array}$ & $0(0 \%)$ & $0(0 \%)$ & $0(0 \%)$ & $0(0 \%)$ & $0(0 \%)$ & $0(0 \%)$ \\
\hline Inappropriate & $0(0 \%)$ & $1(25.0 \%)$ & $0(0 \%)$ & $0(0 \%)$ & $0(0 \%)$ & $2(40.0 \%)$ \\
\hline Appropriate & $2(66.7 \%)$ & $2(50.0 \%)$ & $1(100 \%)$ & $1(100 \%)$ & $1(50.0 \%)$ & $1(20.0 \%)$ \\
\hline $\begin{array}{l}\text { Very } \\
\text { appropriate }\end{array}$ & $1(33.3 \%)$ & $1(25.0 \%)$ & $0(0 \%)$ & $0(0 \%)$ & $1(50.0 \%)$ & $2(40.0 \%)$ \\
\hline \multicolumn{7}{|c|}{ Outcome measure for $p R P$} \\
\hline $\begin{array}{l}\text { Very } \\
\text { inappropriate }\end{array}$ & $0(0 \%)$ & $0(0 \%)$ & $0(0 \%)$ & $0(0 \%)$ & $0(0 \%)$ & $0(0 \%)$ \\
\hline Inappropriate & $1(25.0 \%)$ & $3(60.0 \%)$ & $1(100 \%)$ & $2(100 \%)$ & $1(50.0 \%)$ & $3(60.0 \%)$ \\
\hline Appropriate & $2(50.0 \%)$ & $1(20.0 \%)$ & $0(0 \%)$ & $0(0 \%)$ & $0(0 \%)$ & $2(40.0 \%)$ \\
\hline $\begin{array}{l}\text { Very } \\
\text { appropriate }\end{array}$ & $1(25.0 \%)$ & $1(20.0 \%)$ & $0(0 \%)$ & $0(0 \%)$ & $1(50.0 \%)$ & $0(0 \%)$ \\
\hline \multicolumn{7}{|c|}{ Outcome measure for sRP to CTD } \\
\hline $\begin{array}{l}\text { Very } \\
\text { inappropriate }\end{array}$ & $0(0 \%)$ & $0(0 \%)$ & $0(0 \%)$ & $0(0 \%)$ & $0(0 \%)$ & $0(0 \%)$ \\
\hline Inappropriate & $0(0 \%)$ & $2(40.0 \%)$ & $1(100 \%)$ & $1(100 \%)$ & $0(0 \%)$ & $2(40.0 \%)$ \\
\hline Appropriate & $3(75.0 \%)$ & $2(40.0 \%)$ & $0(0 \%)$ & $0(0 \%)$ & $2(100 \%)$ & $2(40.0 \%)$ \\
\hline $\begin{array}{l}\text { Very } \\
\text { appropriate }\end{array}$ & $1(25.0 \%)$ & $1(20.0 \%)$ & $0(0 \%)$ & $0(0 \%)$ & $0(0 \%)$ & $1(20.0 \%)$ \\
\hline \multicolumn{7}{|c|}{ Outcome measure for sRP to SSc } \\
\hline $\begin{array}{l}\text { Very } \\
\text { inappropriate }\end{array}$ & $0(0 \%)$ & $0(0 \%)$ & $0(0 \%)$ & $0(0 \%)$ & $0(0 \%)$ & $0(0 \%)$ \\
\hline Inappropriate & $0(0 \%)$ & $2(40.0 \%)$ & $1(100 \%)$ & $1(100 \%)$ & $0(0 \%)$ & $2(40.0 \%)$ \\
\hline Appropriate & $2(66.7 \%)$ & $2(40.0 \%)$ & $0(0 \%)$ & $0(0 \%)$ & $2(100 \%)$ & $2(40.0 \%)$ \\
\hline $\begin{array}{l}\text { Very } \\
\text { appropriate }\end{array}$ & $1(33.3 \%)$ & $1(20.0 \%)$ & $0(0 \%)$ & $0(0 \%)$ & $0(0 \%)$ & $1(20.0 \%)$ \\
\hline
\end{tabular}

